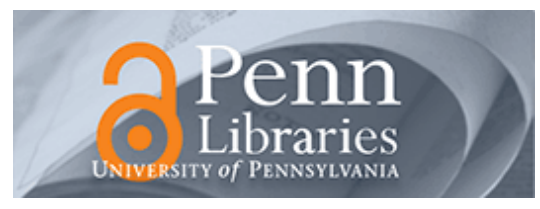

University of Pennsylvania

ScholarlyCommons

Accounting Papers

Wharton Faculty Research

$9-2014$

\title{
Accounting Standards Harmonization and Financial Statement Comparability: Evidence From Transnational Information Transfer
}

Clare Wang

University of Pennsylvania

Follow this and additional works at: https://repository.upenn.edu/accounting_papers

Part of the Accounting Commons

\section{Recommended Citation}

Wang, C. (2014). Accounting Standards Harmonization and Financial Statement Comparability: Evidence From Transnational Information Transfer. Journal of Accounting Research, 52 (4), 955-992.

http://dx.doi.org/10.1111/1475-679X.12055

This paper is posted at ScholarlyCommons. https://repository.upenn.edu/accounting_papers/28

For more information, please contact repository@pobox.upenn.edu. 


\title{
Accounting Standards Harmonization and Financial Statement Comparability: Evidence From Transnational Information Transfer
}

\begin{abstract}
This paper investigates whether accounting standards harmonization enhances the comparability of financial information across countries. I hypothesize that a firm yet to announce earnings reacts more strongly to the earnings announcement of a foreign firm when both report under the same rather than different accounting standards. My analysis of abnormal price reactions for a global sample of firms supports the prediction. Next, in an attempt to control for the underlying economic comparability and the effects of changes in reporting quality, I use a difference-in-differences design around the mandatory introduction of International Financial Reporting Standards. I find that mandatory adopters experience a significant increase in market reactions to the release of earnings by voluntary adopters compared to the period preceding mandatory adoption. This increase is not observed for nonadopters. Taken together, the results show that accounting standards harmonization facilitates transnational information transfer and suggest financial statement comparability as a direct mechanism.
\end{abstract}

\section{Disciplines}

Accounting 


\title{
Accounting Standards Harmonization and Financial Statement Comparability: Evidence from Transnational Information Transfer
}

\author{
Clare Wang \\ The Wharton School \\ University of Pennsylvania \\ wclare@wharton.upenn.edu
}

Current Version: January 2011

\begin{abstract}
This study investigates whether harmonization of accounting standards enhances the comparability of financial information across countries. First, I statistically define and link comparability to firm value in a two-firm, sequential information release framework. I then empirically test the prediction that a firm yet to announce earnings reacts more strongly to the earnings announcement of a foreign firm when both report under the same rather than different accounting standards. My analysis of abnormal price and volume reactions for a global sample of firms supports this prediction. Next, in an attempt to control for the effects of changes in reporting quality, I use a difference-in-differences design around the mandatory introduction of International Financial Reporting Standards (IFRS). I find that mandatory adopters experience a significant increase in market reactions to the release of earnings by voluntary adopters compared to pre-mandatory adoption. This increase is not observed for non-adopters over the same period. Taken together, my study shows that accounting standards harmonization facilitates transnational information transfer, and suggests comparability as a direct mechanism.
\end{abstract}

I thank my dissertation committee members Brian Bushee, Luzi Hail, Catherine Schrand (Chair) and Robert Verrecchia for their continuous and invaluable guidance. I also thank Gus De Franco, Wayne Guay, Mirko Heinle, Ray Ke and Rick Lambert for their helpful comments. I gratefully acknowledge the financial support from the Wharton School and the Connie K. Duckworth Endowed Doctoral Fellowship. 


\section{Introduction}

This study seeks to enhance our understanding of financial statement comparability's benefits for market participants, asking whether harmonization of accounting standards achieves comparability across countries. In a transnational intra-industry information transfer context, I predict and find that a firm's price and volume reactions to a foreign firm's earnings announcement are significantly higher for firms reporting under the same rather than different accounting standards. The intuition is that when the underlying measurement processes for accounting earnings are more correlated, i.e., when they are more comparable, investors can better harness value-relevant information embedded in the foreign firm's earnings signal.

Financial statement comparability has been recognized as an important characteristic of financial reporting, improving the usefulness of accounting information. Broadly, economic decision-making compares alternatives and accounting textbooks emphasize that financial results cannot be evaluated in isolation. Libby, Libby and Short (2009, p.714), for example, maintain that "[a]nalyzing financial data without a basis for comparison is impossible." The importance of financial statement comparability across firms is further underscored in valuation techniques such as price multiples, which are used extensively by investment banks and institutional investors. Consequently, standard setters position comparability as a central feature of the financial reporting system. Specifically, comparability is one of the four "enhancing qualitative characteristics" of accounting information defined in the first phase of the joint conceptual framework completed by the International Accounting Standards Board (IASB) and the Financial Accounting Standards Board (FASB) (IASB, 2010; FASB, 2010).

Financial statement comparability, however, is inherently difficult to define and operationalize. Even theoretically, the effect of comparability on equity valuation is not definitive. A few empirical studies investigate the role of comparability in different contexts including a firm's overall information environment (e.g., De Franco, Kothari and Verdi, 2010; Lang, Maffett and Owens, 2010; Bradshaw, Miller and Serafeim, 2009), mutual fund holdings 
(e.g., DeFond, Hu, Hung, and Li, 2009; Yu, 2010) and use of relative performance evaluation (e.g., Wu and Zhang, 2010). Yet these studies provide mixed evidence and do not directly address the effect of comparability in equity valuation. Moreover, in studies that examine the firm's own economic consequences to test the effects of comparability, a first order reporting quality effect as an alternative explanation for the results is difficult to rule out.

I propose a statistical definition of comparability, which allows me to motivate an equity valuation role for comparability in a theoretical framework. My definition of comparability relies on one descriptive feature of any accounting system: GAAP financial statements measure firm value with error (Barth, Clinch and Shibano, 1999; Christensen, 2010), which I term accounting standards measurement error, or simply measurement error. ${ }^{1}$ I define financial statement comparability as the correlation between the measurement errors from information signals across two firms. ${ }^{2}$

I incorporate this definition of comparability into a two-firm, sequential information release framework and derive empirical predictions on the transfer of information from a firm's earnings announcement to a firm yet to announce earnings. The information transfer context is useful for identifying the comparability effect empirically as it is a direct, short-window test of how one firm's information signal affects the other firm's valuation. I show that the non-announcing firm's market reactions to the announcing firm's earnings report increase with the correlation between the measurement errors, as a higher correlation allows investors to infer more information from the announcing firm's earnings signal when valuing the non-announcing firm. While these outcomes may seem intuitive, my analysis highlights the constraints in a rational expectations framework (e.g., Holthausen and Verrecchia, 1988) and the necessary modifications that deliver these predictions.

\footnotetext{
${ }^{1}$ Admittedly, equity valuation is just one of the objectives of financial reporting. The term "accounting standards measurement error" does not imply that the sole objective of accounting standards is to measure firm value.

${ }^{2}$ An equivalent way to convey this notion of comparability is the correlation between the measurement processes of true economic value across two firms.
} 
I test the prediction that comparability affects the degree of information transfer in two cross-border settings leveraging the ongoing global convergence towards International Financial Reporting Standards (IFRS). Harmonization of accounting standards offers a powerful treatment effect where the increase in correlation between measurement errors should be significant and visible based on a change of the entire system for preparing and disclosing information. In theory, if two firms with the same economic activities report under the same standards, then the measurement errors should be perfectly correlated. ${ }^{3}$ If two firms report under different standards, then the correlation between measurement errors will depend on the specific standards. For example, one would expect the correlation resulting from applications of IFRS and U.S. GAAP to be relatively high in comparison to the correlation resulting from applications of IFRS and Greek GAAP. ${ }^{4}$ Consequently, I expect that the non-announcing firms' price and volume reactions to an earnings announcement by the foreign firm to be higher for firms reporting under the same (more correlated) accounting standards than for firms reporting under different (less correlated) accounting standards.

However, there are at least two reasons why my predictions may not be borne out empirically. First, extant literature shows that a mere switch to a common set of accounting standards is not sufficient to change the properties of accounting numbers as a result of countries' institutional framework and firms' reporting incentives. ${ }^{5}$ Second, any observed effects are confounded by the reporting quality effect of accounting standards, making it

\footnotetext{
${ }^{3}$ In general, any set of accounting standards accommodates accounting method choices. As a simplification on the conceptual level, I assume that the firms make the same accounting method choices to yield perfect correlation in measurement errors under the same accounting standards. I do not intend to imply that descriptively no difference in accounting method choices is associated with using the same standards. My empirical tests (1) capture the extent to which the same accounting standards narrows down the set of available accounting method choices and (2) employ cross-sectional analyses and difference-in-differences design to partially account for the heterogeneity in method choices.

${ }^{4}$ Bae, Tan and Welker (2008) constructs a summary score of how local GAAP differ from IFRS on 21 accounting dimensions. Greek GAAP differs from IFRS on 17 dimensions while U.S. GAAP differs from IFRS on four dimensions only. Greek GAAP, for example, does not require a cash flow statement, segment reporting, or disclosure of the fair value of financial assets and liabilities.

${ }^{5}$ See Ball, Kothari and Robin, 2000; Ball, Robin and Wu, 2003; Leuz, Nanda and Wysocki, 2003; Burgstahler, Hail and Leuz, 2006.
} 
difficult to isolate the comparability effect.

My empirical strategy pursues two distinct sets of tests to address these issues. First, I perform a pooled sample levels analysis based on the traditional information transfer research design. ${ }^{6}$ I examine market reactions for a sample of 575 earnings announcements from global industry leaders for the period from 2001 to 2008. The main result is that both abnormal price and volume reactions to earnings announcement are significantly higher for non-announcing firms using the same standards in comparison to non-announcing firms using different standards. Further results from cross-sectional analyses highlight the importance of legal enforcement and reporting incentives for achieving the desired transnational comparability. In line with the notion that some firms may simply adopt IFRS as a label (Daske, Hail, Leuz and Verdi, 2009), the greater information transfer effect from using the same accounting standards is significant only for announcing firms domiciled in countries with stricter enforcement regimes and stronger reporting incentives.

My second set of analyses exploits a unique institutional feature of country-level mandatory IFRS adoption to isolate the comparability effects from the reporting quality effects of accounting standards. Firms have voluntarily adopted IFRS as early as the 1990s for reasons such as cross-listing. In theory, for this group of voluntary IFRS adopters (hereafter voluntary adopters), the subsequent country-level mandatory IFRS adoption should not alter the quality of their earnings signals. Holding the quality of the earnings signals constant, I identify the comparability effect by evaluating the time-series changes in market reactions for a group of treatment firms (i.e., mandatory IFRS adopters, hereafter mandatory adopters) against a group of benchmark firms (i.e., non-IFRS adopters, hereafter non-adopters). The intuition is that while both groups observe the same earnings signal, only the treatment group incurs a comparability benefit by moving to the same accountings standards. Consequently,

\footnotetext{
${ }^{6}$ Examples include information transfer associated with earnings announcements (Firth, 1976; Foster, 1981; Clinch and Sinclair, 1987; Freeman and Tse, 1992; Han and Wild, 1990; Ramnath, 2002; Thomas and Zhang, 2008) and management forecasts of earnings (Baginski, 1987; Han, Wild and Ramesh, 1989; Pyo and Lustgarten, 1990; Kim, Lacina and Park, 2008).
} 
I perform a difference-in-differences analysis that compares the information transfer effects before and after the country-level mandatory IFRS adoption for a sample of 834 earnings announcements from voluntary adopters. The main results, supported by both univariate and multivariate analyses, show that non-announcing firms that are mandatory adopters experience significant increases in market reactions to voluntary adopters' earnings signals post-mandatory adoption. Non-adopters, meanwhile, do not experience these increases in market reactions over the same period.

This study contributes to several strands of literature. First, it provides evidence on the importance of comparability in general. Results from this study lend support to the prediction that non-announcing firm's price and volume reactions to announcing firm's information signal increase with the correlation across measurement errors of the signals. There is limited evidence on the benefits of comparability in an equity valuation context to date. This study defines comparability statistically and shows that better comparability across information signals allows investors to better harness the additional signal in forming price expectations.

This study also contributes to the stream of research that investigates the economic benefits of mandatory IFRS adoption and is relevant to the ongoing policy deliberation regarding the convergence of U.S. GAAP and IFRS. Specifically, my empirical test is a joint test of two hypotheses: that accounting standards harmonization increases financial statement comparability and that comparability plays an important role in equity valuation. The IASB cites "higher quality, transparency and comparability" as primary objectives and benefits of IFRS. While any reduction in the magnitude of measurement error represents a reporting quality benefit, the increase in correlation across measurement errors represents a comparability benefit. My research design aims to hold the reporting quality constant, thus presenting clean evidence for the comparability benefits from harmonization of accounting standards.

Finally, this study presents direct evidence on information transfer in a cross-country 
setting. The scope of prior research has been limited almost exclusively to information transfer between domestic firms. ${ }^{7}$ However, as the global economy and capital markets become more integrated, information released by firms in one country becomes more relevant for firms domiciled in other countries. The magnitude of transnational information transfer is expected to be a function of various institutional factors (Firth, 1996). This paper identifies and investigates in detail one of the institutional factors, namely accounting standards.

The subsequent section reviews extant literature and develops my hypotheses. Section 3 describes the sample and data. Section 4 delineates my research design for the levels analyses and presents results for whether using the same accounting standards increases the transnational information transfer effects. Section 5 examines the same question using a difference-in-differences approach. Section 6 tests the robustness of the results, and Section 7 concludes.

\section{Background and Hypothesis Development}

\subsection{Financial Statement Comparability}

While comparability is often advocated, direct examination of the comparability effect is nascent. De Franco et al. (2010) develop an output-based measure of comparability based on the earnings and stock returns relation, capturing the similarity with which the accounting systems of two firms translate a given firm's economic shock. Their study finds that higher comparability lowers the cost of acquiring information and improves the overall information environment for U.S. firms. Bradshaw et al. (2009) measure comparability using commonality of accounting choices, and find that the use of atypical accounting methods is associated with larger analyst forecast errors and forecast dispersion. These two studies test the effect of comparability within a single set of accounting standards.

\footnotetext{
${ }^{7}$ Two exceptions are Firth (1996) and Alves, Pope and Young (2007). Firth (1996) shows the existence of information transfers associated with earnings releases in a two-country context (U.S. and U.K.). Alves et al. (2007) find evidence for transnational information transfer associated with profit warnings for a sample of European firms.
} 
Using mandatory IFRS adoption, several papers investigate the comparability effect of accounting standards harmonization and find mixed evidence. Beuselinck, Joos and Van der Meulen (2008) present early evidence that mandatory IFRS adoption does not instantly deliver improvement in earnings comparability across Europe in terms of the accruals cash flow association. Most recently, Lang et al. (2010) use the De Franco et al. (2010) measure and conclude that accounting comparability does not increase for IFRS adopters relative to a benchmark group of non-adopters. They also find negative effects on the firms' information environments, which suggests accounting standards harmonization does not improve in analysts' ability to learn from inter-firm comparisons. On the other hand, DeFond et al. (2009) create two input-based measures (i.e., the reduction in the heterogeneity of accounting standards in an industry and the increase in peer firms using the same accounting standards) and evaluate the comparability effects from foreign investors' perspective. They find that post-mandatory IFRS adoption, foreign mutual fund ownership increases for firms that experience large increases in comparability with other firms in the same industry. $\mathrm{Wu}$ and Zhang (2010) infer changes in financial reporting comparability through changes in the use of relative performance evaluation (RPE). They find a post-adoption increase in the use of RPE based on foreign peers' accounting information, consistent with mandatory IFRS adoption enhances comparability for firms in continental Europe.

Other studies indirectly shed light on the comparability effect of accounting standards. Daske, Hail, Leuz and Verdi (2008) find that mandatory IFRS adoption results in increased capital market liquidity, but only in countries with strict enforcement regimes and institutional environments that provide strong reporting incentives. While Daske et al. (2008) conjecture that one reason for the increased liquidity is improved comparability, their analysis finds an insignificant effect. Armstrong, Barth, Jagolinzer and Riedl (2010) find that stock prices of EU firms reacted positively to news during 2002 that IFRS would become mandatory in 2005. In particular, their study finds positive market reaction for firms with higher quality information pre-mandatory adoption, consistent with benefits arising from 
comparability in addition to quality. Yu (2010) tests whether mandatory IFRS adoption reduces home bias by examining the change in international mutual fund ownership. Her study finds that mutual fund ownership increases after mandatory adoption, and that the increase is larger in countries where the distance between the mutual funds' home GAAP and the adopting firm's home GAAP tends to be larger.

My study differs from these studies in two respects. First, I investigate the effects of comparability in an equity valuation context and provide a simple theoretical framework that formalizes the intuition. I define improved comparability by an increase of correlation between accounting standards measurement errors and show how it links to firm value in an information transfer setting. Second, my paper exploits a unique institutional feature of country-level mandatory IFRS adoption to isolate the comparability effect from the reporting quality effect of accounting standards. Using a difference-in-differences design based on mandatory adopters and non-adopters' market reactions to earnings announcement by voluntary adopters around the IFRS mandate, I attempt to hold the reporting quality effect constant and provide clean evidence on the comparability effect of accounting standards harmonization.

\subsection{Hypothesis Development}

To structure my empirical predictions, I statistically define comparability and present a simple theoretical characterization to motivate an equity valuation role for comparability in an information transfer context. I adapt a two-firm, sequential information release framework from Houthausen and Verrecchia (1988, hereafter HV), and study one firm's market reactions to earnings announcement by the other firm when both report under the same accounting standards versus different accounting standards.

Consider a perfectly competitive and risk neutral market with two firms $(i=1,2)$. The

terminal values of both firms $\left(\widetilde{V}_{i}\right)$ are normally distributed with mean $\mu_{i}$ and variance $\sigma_{v_{i}}^{2}$, and the terminal values are correlated with correlation coefficient $\rho_{v}$, which represents the underlying economic link between the two firms. Each firm issues an earnings report $r_{i}$, 
which investors use to derive the price of each firm. Reported earnings can be thought of as the outcome of fundamental economic events coupled with the accounting for those events (Dechow, Ge and Schrand, 2010; Fischer and Verrecchia, 2000). Thus, each earnings report is garbled by an accounting standards measurement error denoted $\widetilde{\eta}_{i}$, which is normally distributed with mean 0 and variance $\sigma_{\eta_{i}}^{2}$ and is independent of $\widetilde{V}_{i}{ }^{8}$

I operationalize comparability by asserting that measurement errors are correlated across different accounting standards and interpret this correlation as financial statement comparability. In particular, I denote $\rho_{\eta}$ to be the correlation between the measurement errors across two accounting standards. For example, if the two firms report under the same standard, then $\rho_{\eta}=1$, and $\operatorname{Cov}\left[\widetilde{\eta}_{1}, \widetilde{\eta}_{2}\right]=\sigma_{\eta_{1}} \sigma_{\eta_{2}}$ by construction. This interpretation is consistent with Barth et al. (1999) where the authors operationalize accounting standards harmonization as identical measurement errors that are perfectly correlated. Under these assumptions, distributions of the earnings reports are as follows:

$$
\widetilde{R} \sim\left[\left(\begin{array}{c}
\mu_{1} \\
\mu_{2}
\end{array}\right),\left(\begin{array}{cc}
\sigma_{v_{1}}^{2}+\sigma_{\eta_{1}}^{2} & \rho_{v} \sigma_{v_{1}} \sigma_{v_{2}}+\rho_{\eta} \sigma_{\eta_{1}} \sigma_{\eta_{2}} \\
\rho_{v} \sigma_{v_{1}} \sigma_{v_{2}}+\rho_{\eta} \sigma_{\eta_{1}} \sigma_{\eta_{2}} & \sigma_{v_{2}}^{2}+\sigma_{\eta_{2}}^{2}
\end{array}\right)\right]
$$

From the covariance structure in eqn. (1), it is clear that Firm1's earnings report may help investors to make predictions of Firm2's true economic performance. The usefulness of Firm1's report is a function of both the level of economic similarity (i.e., correlation between the underlying economics across the two firms, $\rho_{v}$ ) and the level of financial statement comparability (i.e., correlation between measurement errors across the two reports, $\left.\rho_{\eta}\right) .^{9}$

\footnotetext{
${ }^{8}$ This definition of measurement error is consistent with the descriptive feature of GAAP reports measuring firm value with error (Barth et al., 1999, footnote 4; Christensen, 2010). I abstract from "misreporting errors" that arise from firms' incentives to misreport in this context as they are independent from the extent to which accounting standards across reporting regimes introduce correlated measurement errors. See Fischer and Verrecchia (2000) for an analysis that incorporates misreporting error in deriving the theoretical measure of the earnings response coefficient in a single-firm setting.

${ }^{9}$ Consistent with the positive and negative information transfer effects described in detail later in this section, I assume the economic correlation between firms may be positive or negative (i.e., $\left.-1 \leq \rho_{v} \leq 1\right)$. I assume the correlation between accounting standards measurement errors is positive (i.e., $0 \leq \rho_{\eta} \leq 1$ ).
} 
Given the sequential reporting structure, without loss of generality, I assume Firm1 releases its earnings report at $t=1$ before Firm2 releases its earnings report at $t=2 .{ }^{10}$ Figure 1, Panel A depicts the timeline of events. Figure 1, Panel B summarizes the price function of Firm2 at each time period in the original HV model. In a rational expectations framework, the price of Firm2 at Firm1's earnings report date $t=1$ is:

$$
P_{2}^{t=1}=E\left[\tilde{V}_{2} \mid \tilde{r}_{1}=r_{1}\right]=\mu_{2}+\frac{\rho_{v} \sigma_{v_{1}} \sigma_{v_{2}}}{\sigma_{v_{1}}^{2}+\sigma_{\eta_{1}}^{2}}\left(r_{1}-\mu_{1}\right)
$$

Eqn. (2) suggests that financial statement comparability, $\rho_{\eta}$, plays no role in Firm2's equity valuation when Firm1 releases its earnings report at $t=1$. The coefficient on Firm1's report is a function of the underlying economic similarity, $\rho_{v}$, and other variance terms. The absence of $\rho_{\eta}$ is because the covariance between Firm2's terminal value $\tilde{V}_{2}$ and Firm1's report $\tilde{r}_{1}$ does not depend on the correlation of measurement errors between the two firms' reports. ${ }^{11}$ This result is at odds with real world institutional settings, where information transfer effect occurs at $t=1$ and financial reporting comparability plays a role. Consequently, I adapt the framework in order to yield the possibility that measurement error correlation matters at $t=$ 1. I obtain this result by introducing two additional assumptions to the HV model outlined in Figure 1, Panel C. In short, the results relax the assumption of investors being perfectly rational and allow for short-lived investors. While there are other potential approaches that can deliver the same result, I believe my approach the most parsimonious. ${ }^{12}$

First, I assume that at period $t=2$ when Firm2 releases its own report, investors price

Finally, I assume measurement error correlation is only relevant when there is economic correlation, that is: if $\rho_{v}=0$, then $\rho_{\eta}=0$ by construction.

${ }^{10}$ I define Firm1 as the announcing firm and Firm2 as the non-announcing firm and refer to these definitions interchangeably for ease of exposition.

${ }^{11}$ Figure 1, Panel B shows that financial statement comparability plays a role in Firm2's equity valuation when Firm2 releases its earnings report at $\mathrm{t}=2$. However, conducting empirical tests for the importance of Firm1's report at $\mathrm{t}=2$ suffers from weak power since the equity valuation effects are likely to be dominated by the information content of Firm2's own report.

${ }^{12}$ See Appendix A for an alternative explanation for why correlation may matter. 
Firm2 based solely on its own report and ignore Firm1's earlier report. ${ }^{13}$ Thus, I conjecture that the price of Firm2 at $t=2$ is

$$
P_{2}^{t=2}=E\left[\tilde{V}_{2} \mid \tilde{r}_{2}=r_{2}\right]=\mu_{2}+\frac{\sigma_{v_{2}}^{2}}{\sigma_{v_{2}}^{2}+\sigma_{\eta_{2}}^{2}}\left(r_{2}-\mu_{2}\right)
$$

Intuitively, eqn. (3) provides the expression for firm value that results from regressing terminal value, $\tilde{V}_{2}$, on reported earnings, $r_{2}$. Eqn. (3) implies that the market price is a linear function of the report: $P_{2}^{t=2}=\alpha+\beta r_{2}$ where

$$
\beta=\frac{\sigma_{v_{2}}^{2}}{\sigma_{v_{2}}^{2}+\sigma_{\eta_{2}}^{2}}
$$

$\beta$ represents the earnings response coefficient (ERC) to Firm2's own report. It is always positive, thereby reflecting a positive association between firm prices and earnings surprises, and is decreasing in $\sigma_{\eta_{2}}^{2}$ because less measurement error in reported earnings implies greater price-earnings association. In other words, earnings reports are expected to have a greater effect on equity valuation of the firm when the reported numbers more accurately reflect true economic value. This relation represents the role of accounting standards measurement error in a single-firm setting.

Next, I consider the effect of the realization of a report of Firm1 at $t=1$, i.e., $\tilde{r}_{1}=r_{1}$, on the price of Firm2. In this step, I propose my second assumption that investors use Firm1's report to predict Firm2's price at the next period (i.e., $\tilde{P}_{2}^{t=2}$ ), and they rely on $\tilde{P}_{2}^{t=2}$ instead of terminal value $\tilde{V}_{2}$ for this period's valuation. ${ }^{14}$ Consequently, Firm2's price at

\footnotetext{
${ }^{13}$ This assumption relates to individual investor's behavioral biases in information processing (e.g., limited attention and capacity in Hirshleifer and Teoh, 2003; Hirshleifer, Lim and Teoh, 2009; overconfidence in Daniel, Hirshleifer and Subrahmanyam, 1998, 2001; Hong and Stein, 1999).

${ }^{14}$ This assumption relates to investor "short-termism," which may be caused by noise trader risk (DeLong, Shleifer, Summers and Waldmann, 1990), limits to arbitrage (Shleifer and Vishny, 1997), or rational structural uncertainty associated with parameter estimation for uncertain outcomes (Brav and Heaton, 2002).
} 
$t=1$ conditional on Firm1's earnings report at $t=1$ is

$$
P_{2}^{t=1}=E\left[\tilde{P}_{2}^{t=2} \mid \tilde{r}_{1}=r_{1}\right]=\mu_{2}+\frac{\sigma_{v_{2}}^{2}}{\sigma_{v_{2}}^{2}+\sigma_{\eta_{2}}^{2}} \frac{\rho_{v} \sigma_{v_{1}} \sigma_{v_{2}}+\rho_{\eta} \sigma_{\eta_{1}} \sigma_{\eta_{2}}}{\sigma_{v_{1}}^{2}+\sigma_{\eta_{1}}^{2}}\left(r_{1}-\mu_{1}\right)
$$

Consistent with the information transfer literature, eqn. (5) expresses the relation between $P_{2}^{t=1}$, the price of Firm2 at $t=1$, based on a report by Firm1 (i.e., $r_{1}$ ) at $t=1$. More importantly, in contrast to eqn. (2), incorporating the two assumptions delivers a modified HV framework where comparability, defined as $\rho_{\eta}$, has an important role in the price function of Firm2 at $t=1$. Based on eqn. (5), the market price of Firm2 at $t=1$ is a linear function of Firm1's report: $P_{2}^{t=1}=\alpha^{\prime}+\gamma r_{1}$ where

$$
\gamma=\frac{\sigma_{v_{2}}^{2}}{\sigma_{v_{2}}^{2}+\sigma_{\eta_{2}}^{2}} \frac{\rho_{v} \sigma_{v_{1}} \sigma_{v_{2}}+\rho_{\eta} \sigma_{\eta_{1}} \sigma_{\eta_{2}}}{\sigma_{v_{1}}^{2}+\sigma_{\eta_{1}}^{2}}=\beta \frac{\rho_{v} \sigma_{v_{1}} \sigma_{v_{2}}+\rho_{\eta} \sigma_{\eta_{1}} \sigma_{\eta_{2}}}{\sigma_{v_{1}}^{2}+\sigma_{\eta_{1}}^{2}}
$$

Eqn. (6) represents $\gamma$, the earnings response coefficient to Firm1's report, or the information transfer ERC. It is a function of all the exogenous parameters including $\rho_{\eta}$ and $\rho_{v}$. From eqn. (6), it is intuitive that if Firm1 and Firm2 are identical firms (i.e., $\rho_{v}=\rho_{\eta}=1, \sigma_{v_{1}}=\sigma_{v_{2}}=\sigma_{v}$ and $\left.\sigma_{\eta_{1}}=\sigma_{\eta_{2}}=\sigma_{\eta}\right)$, then $\gamma$ reduces to $\beta$, Firm2's earnings response coefficient to its own report as defined in eqn. (4). If there is no correlation between accounting standards measurement errors (i.e., $\rho_{\eta}=0$ ), the sign of $\gamma$ is dependent on the sign of $\rho_{v}$, the correlation between the two firms' underlying economics. If $\rho_{v}>0$, then $\gamma>0$, and vice versa. This result supports the notion of positive and negative information transfer (Lang and Stulz, 1992; Laux, Starks and Yoon, 1998; Kim et al., 2008). The intuition is that positive correlation in firms' underlying economics reflects industry commonality, which manifests as positive information transfer, while negative correlation is more likely to reflect competitive rivalry, which manifests as negative information transfer. In my characterization with correlated measurement errors (i.e., $\rho_{\eta}>0$ ), there is a countervailing force in some cases. Specifically, if the positive correlation in measurement errors is high enough to offset the negative correlation in underlying economics, $\gamma$ is positive despite the negative information 
transfer from the underlying competitive shift. Consequently, the sign of $\gamma$, the information transfer ERC, is dependent on the interplay between the two correlation terms and the other parameters chosen.

At the start of the period $t=0$ with no consideration for any information signal, the price of Firm2 is $E\left[\tilde{V}_{2}\right]=\mu_{2}$. Thus, the stock price response of Firm2 to Firm1's earnings announcement is measured by

$$
\begin{aligned}
\delta_{2} & =P_{2}^{t=1}-\mu_{2} \\
& =\frac{\sigma_{v_{2}}^{2}}{\sigma_{v_{2}}^{2}+\sigma_{\eta_{2}}^{2}} \frac{\rho_{v} \sigma_{v_{1}} \sigma_{v_{2}}+\rho_{\eta} \sigma_{\eta_{1}} \sigma_{\eta_{2}}}{\sigma_{v_{1}}^{2}+\sigma_{\eta_{1}}^{2}}\left(r_{1}-\mu_{1}\right) \\
& =\gamma\left(r_{1}-\mu_{1}\right),
\end{aligned}
$$

which is a linear function of Firm1's earnings surprise.

My primary interest is in the relation between $\rho_{\eta}$, the correlation between accounting standards measurement errors, and $\gamma$, the information transfer ERC. Differentiate $\gamma$ with respect to $\rho_{\eta}$ :

$$
\frac{\partial \gamma}{\partial \rho_{\eta}}=\frac{\sigma_{v_{2}}^{2} \sigma_{\eta_{1}} \sigma_{\eta_{2}}}{\left(\sigma_{v_{2}}^{2}+\sigma_{\eta_{2}}^{2}\right)\left(\sigma_{v_{1}}^{2}+\sigma_{\eta_{1}}^{2}\right)}>0 .
$$

Consistent with intuition, higher correlation leads to an increase in the earnings association of Firm1's report for Firm2's pricing since more can be learned from Firm1's measurement error about Firm2's measurement error. Thus, the price response to earnings surprise is higher for firms reporting under the same accounting standards rather than different accounting standards. This insight leads to the following hypothesis in alternative form and provides the basis for my empirical tests with respect to price change.

H1: The magnitude of the price reaction to transnational earnings information transfers is greater for firm-pairs using the same accounting standards than for those using different accounting standards.

Next, I characterize Firm2's trading volume reaction to Firm1's earnings report in the same framework. While price change reflects the change in expectations of the market as 
a whole, trading volume reflects the change in expectations of individual investors (Beaver, 1968). As the correlation between measurement errors increases the information content of Firm1's earnings report for Firm2's equity valuation, I expect Firm2's investors to interpret this signal more dissimilarly and trade more as a result. Kim and Verrecchia (1991) show that the trading volume reaction to public announcement is proportional to the absolute price change at the time of the announcement. Therefore, an expression for the expected absolute price change provides a theoretical link to predictions with respect to trading volume reaction. I calculate Firm2's expected absolute price change as:

$$
\begin{aligned}
E\left[\left|\delta_{2}\right|\right] & =E\left[\left|\frac{\sigma_{v_{2}}^{2}\left(\rho_{v} \sigma_{v_{1}} \sigma_{v_{2}}+\rho_{\eta} \sigma_{\eta_{1}} \sigma_{\eta_{2}}\right)}{\left(\sigma_{v_{2}}^{2}+\sigma_{\eta_{2}}^{2}\right)\left(\sigma_{v_{1}}^{2}+\sigma_{\eta_{1}}^{2}\right)}\left(r_{1}-\mu_{1}\right)\right|\right] \\
& =\left|\frac{\sigma_{v_{2}}^{2}\left(\rho_{v} \sigma_{v_{1}} \sigma_{v_{2}}+\rho_{\eta} \sigma_{\eta_{1}} \sigma_{\eta_{2}}\right)}{\sigma_{v_{2}}^{2}+\sigma_{\eta_{2}}^{2}}\right| \sqrt{\frac{2}{\pi}}\left(\sigma_{v_{1}}^{2}+\sigma_{\eta_{1}}^{2}\right)^{-1 / 2} .
\end{aligned}
$$

Differentiate Firm2's expected absolute price change $E\left[\left|\delta_{2}\right|\right]$ with respect to $\rho_{\eta}$, the correlation between accounting standards measurement errors:

$$
\begin{gathered}
\frac{\partial E\left[\left|\delta_{2}\right|\right]}{\partial \rho_{\eta}}=\frac{\sigma_{v_{2}}^{2} \sigma_{\eta_{1}} \sigma_{\eta_{2}}}{\sigma_{v_{2}}^{2}+\sigma_{\eta_{2}}^{2}}>0 \text { if } \rho_{v} \sigma_{v_{1}} \sigma_{v_{2}}+\rho_{\eta} \sigma_{\eta_{1}} \sigma_{\eta_{2}}>0 \\
\frac{\partial E\left[\left|\delta_{2}\right|\right]}{\partial \rho_{\eta}}=-\frac{\sigma_{v_{2}}^{2} \sigma_{\eta_{1}} \sigma_{\eta_{2}}}{\sigma_{v_{2}}^{2}+\sigma_{\eta_{2}}^{2}}<0 \text { if } \rho_{v} \sigma_{v_{1}} \sigma_{v_{2}}+\rho_{\eta} \sigma_{\eta_{1}} \sigma_{\eta_{2}}<0 .
\end{gathered}
$$

The result is ambiguous due to the initial assumption that the firms' underlying economics may be positively or negatively correlated. If the contagion effect dominates the competitive shift effect (i.e., $\rho_{v}>0$ ), the magnitude of the absolute price change is increasing in $\rho_{\eta}$ (i.e., it stands to gain or lose more from the good news or bad news as implied by a peer's earnings announcement), other things being equal. Alternatively, if the competitive shift effect dominates the contagion effect (i.e., $\rho_{v}<0$ ), the magnitude of absolute price change becomes smaller (i.e., less negative) as $\rho_{\eta}$ increases. Thus, the effect of correlation in accounting standards on absolute price change has the same sign as $\gamma$, the information 
transfer ERC.

While the above calculations show ambiguous results, in real world institutional settings, I expect firms' earnings reports to be positively correlated on average (i.e., $\rho_{v}>0$ ). Existing empirical evidence lends support to this parameter assumption. Extant literature suggests that earnings announcements convey more industry-relevant information (contagion) than market power information (competitive). Consequently, for my empirical tests, I assume the effect of correlation between accounting standards on absolute value price change to be positive on average, which leads to the following hypothesis in alternative form.

H2: The magnitude of the volume reaction to transnational earnings information transfers is greater for firm-pairs using the same accounting standards than for those using different accounting standards.

\subsection{Cross-sectional Predictions}

The two primary hypotheses are based on the maintained assumption that accounting standards harmonization can effectively increase the correlation across the accounting standards measurement errors (i.e., increase $\rho_{v}$ ). However, there are reasons why this assumption may not be true. First, there are uncertainties regarding non-compliance and proper enforcement. Based on a study of early users of IFRS, Street and Gray (2001) find that firms are not compliant in meeting even the easily observable disclosure requirements. In addition, Burgstahler et al. (2006) conclude that lax enforcement can result in limited compliance with the standards. Second and more importantly, a stream of literature highlights the importance of firms' reporting incentives, rather than accounting standards, as key drivers of observed properties of accounting outputs (e.g., Ball et al., 2000; Ball et al., 2003). Even with perfect enforcement, observed firm reporting behavior is expected to differ across firms as long as accounting standards offer some discretion and firms have different reporting incentives. Finally, Zeff (2007) discusses how cultural issues interfere with promoting worldwide financial statement comparability. Differences in business and financial culture, such as executive compensation package, organizational structure, and 
degree of capital market development, impact financial statements preparation.

These arguments predict that countries' institutional structures, the economic environment, and preparers' incentives play an important role in financial reporting. All else being equal, firms in countries with stricter enforcement regimes and institutional structures that provide strong reporting incentives are less likely to adopt accounting standards without changing reporting practices. As a result, reported earnings from these firms are more likely to provide information to other firms through the increase in correlation between measurement errors. This discussion leads to the following cross-sectional hypothesis in alternative form.

H3: Post accounting standards harmonization, increases in transnational information transfer effects are greater for announcing firms domiciled in countries with relatively stricter enforcements and stronger reporting incentives.

Next, I examine whether the economic benefits of comparability vary based on characteristics of the firm-pair. First, as shown in eqn. (6), the magnitude of information transfer effects is positively associated with $\rho_{v}$, the correlation coefficient between the two firms' underlying economics. Within the global sample, I argue that firms domiciled in the EU countries have stronger economic ties and are more likely to face common economic shocks due to greater political and economic integration in the region. Second, Tan, Wang and Welker (2009) find that mandatory IFRS adoption attracts foreign analysts and improves forecast accuracy. Given that overlap in information environment facilitates the transmission and processing of the additional information signal, I expect the increase in analyst overlap to improve information flow and enhance investors' equity valuation. Therefore, my final hypothesis in alternative form is as follows:

H4: Post accounting standards harmonization, increases in transnational information transfer effects are greater for firm-pairs with stronger economic ties and overlap in analyst coverage. 


\section{Sample and Data}

As transnational information transfer is likely more difficult to detect than domestic information transfer (Firth, 1996), sample selection is an important consideration. A priori, information transfer effects are likely to exist only for an identifiable subset of firms, rather than for the population of all firms (Foster, 1981). Consequently, I employ sampling procedures that aims to maximize the power of detecting transnational information transfer.

I construct two separate samples for the levels analyses and changes analyses from a firm-year panel dataset. I collect the panel dataset at the intersection of Worldscope (for financial data), Datastream (for price and volume data) and I/B/E/S (for analyst forecast data) for all non-U.S. firms. ${ }^{15}$ The sample covers firms with fiscal years ending on or after January 1, 2001, through December 31, 2008. I divide firms into the Fama French 30 industry groups and exclude regulated industries (i.e., \#29 financials and \#20 utilities) as well as industries with less than 100 firms (i.e., \#3 tobacco products, \#18 coal and \#30 everything else).

For the levels analysis sample, I first identify the announcing firms (i.e., Firm1) in each industry year as the three largest firms according to market value at the end of calendar year. I use the size-based criteria since larger firms' earnings surprises have greater potential for conveying information on other firms in the industry than do smaller firms as they are more likely to be related to information pertaining to the overall economy or industry sector than to firm-specific information (Atiase, 1985; Bamber, 1987; Freeman, 1987). Moreover, larger firms typically represent industry leaders, commanding higher visibility that increases the effectiveness of the information signal (Merton, 1987; Lehavy and Sloan, 2008).

I then identify the non-announcing firms (i.e., Firm2) as the sample of firms other than the announcing firms in the same industry year, but domiciled in a different country. I impose additional requirements to maximize the power of the test. First, I require Firm2 to have

\footnotetext{
${ }^{15}$ International firms that cross-list in the U.S. are included in the sample.
} 
non-zero foreign sales for the year. Conceptually, two firms in different countries but sharing the same industry classification need not be closely related (i.e., $\rho_{v}=0$ ) if the industry concerned is primarily a localized business. In this scenario, earnings of one firm may convey little information about the profitability of another foreign firm with the same SIC code. The requirement on foreign sales attempts to ensure that the chosen Firm2 is a global businesses competing in the same international product market, so that the profitability of Firm1 domiciled in another country is potentially related. Second, Firm2's own earnings release is not within two trading days after Firm1's earnings release. If Firm2's own announcement is this close after Firm1's announcement, then Firm2's own announcement will contaminate the results since a firm's own earnings announcement is arguably the most significant information release in a firm's information environment. Given the two firms may have different fiscal year-end dates, the third requirement is that Firm1 and Firm2 have at least 182 days of overlap in the fiscal year.

Following this procedure, the levels analyses sample consists of 575 earnings announcements by global industry leaders across eight fiscal years, which results in 26,349 firm-pair-year observations. Table 1, Panel A reports the breakdown by countries for the number of announcement, unique announcing firms and observations. The 575 announcements from 136 industry leaders are concentrated in Japan (22.3\%) and the U.K. (19.7\%). Table 1, Panel B provides similar information for the non-announcing firms. There are 4,467 unique firms from 46 countries with the largest concentration in the U.K. (17.3\%) and Canada (7.3\%). Table 1, Panel C reports the sample composition by year and industry.

I construct the changes analyses sample using the same panel dataset with modified selection criteria for the announcing and non-announcing firms. For the group of announcing firms, I begin with the entire group of voluntary adopters and impose a size requirement of US $\$ 1$ billion in market value. The intuition for the size screen is to ensure that the announcing firm has enough visibility in the industry and is followed by investors and analysts. The selection procedures for the non-announcing firms are identical to the 
procedure for the levels analyses sample except voluntary adopters are excluded. In other words, the non-announcing firms are either mandatory adopter or non-adopters. To eliminate the impact of sample composition in the changes analyses, I require each firm-pair to have at least one observation both before and after mandatory IFRS adoption.

The changes analyses sample consists 834 earnings announcements by voluntary adopters, which results in 20,997 firm-pair-year observations. ${ }^{16}$ Table 1, Panel A reports the breakdown by countries for the number of announcements, unique announcing firms and observations. The 834 announcements from 145 voluntary adopters are concentrated in Germany (23.1\%) and Switzerland (17.1\%). Table 1, Panel B provides similar information for the non-announcing firms. There are 1,510 unique firms covering 43 countries with the largest concentration in the U.K. (15.7\%) and France (10.7\%). Table 1, Panel C reports the sample composition by year, industry and the breakdown between treatment and benchmark groups. $58.7 \%$ of the non-announcing firms are mandatory adopters (i.e., treatment group) and the remaining are non-adopters (i.e., benchmark group).

\section{Levels Analyses for Global Sample}

\subsection{Research Design}

My first set of empirical tests follows a traditional information transfer research design. I model the market reaction of the non-announcing firm (i.e., Firm2) by the following two regression equations estimated at the firm-pair-year level:

$$
\begin{aligned}
& \text { MktRea }_{2 t}=\alpha_{0}+\alpha_{1} \text { Same }_{12 t}+\gamma_{1} U E_{1 t}+\gamma_{2} \text { Same }_{12 t} * U E_{1 t}+\sum \beta_{k} \text { Ctrls }_{k}+\varepsilon_{2 t} \\
& M k t R e a_{2 t}=\alpha_{0}+\alpha_{1} C o m p \_H i g h_{12 t}+\gamma_{1} U E_{1 t}+\gamma_{2} C o m p \_H i g h_{12 t} * U E_{1 t}+\sum \beta_{k} C t r l s_{k}+\varepsilon_{2 t}
\end{aligned}
$$

where $M k t R e a_{2 t}$ stands for Firm2's abnormal returns and abnormal volume reaction.

\footnotetext{
${ }^{16}$ As a result of the different sampling procedures, the two samples are fairly independent; there is only an approximately $10 \%$ overlap in terms of firm-pair-year observations.
} 
Firm2's cumulative abnormal returns $\left(C A R_{2 t}\right)$ are estimated using a two factor market model for the $(-1,+1)$ event window around Firm1's earnings announcement day. The market model parameters are estimated over the period from 21 to 220 days before the announcement using returns from a value-weighted local market portfolio and a value-weighted world portfolio. The world market factor in addition to the standard market model aims to account for the heterogeneity in capital markets integration. The $(-1,+1)$ event window is defined to accommodate the differences across international time zones, which may cause Firm1's announcement to reach Firm2 earlier or later in calendar time than the day of the announcement. Firm2's abnormal trading volume $\left(A V O L_{2 t}\right)$ is the natural logarithm of average daily turnover during the event window, and scaled by the median daily turnover during the estimation period. Daily turnover is defined as shares of Firm2 traded during day $t$ divided by total shares outstanding of Firm2 during day $t$.

I operationalize my definition of financial statement comparability, the correlation across accounting standards measurement errors (i.e., $\rho_{\eta}$ ), using two proxies. First, I use an indicator variable $(S A M E)$ equal to one when Firm1 and Firm2 use the same accounting standards and zero otherwise. While this measure has theoretical appeal in that it reflects $\rho_{\eta}=1$ when firms use the same accounting standards, the measure is overly strict in cases when firms use different accounting standards by always assigning $\rho_{\eta}=0$. In other words, it does not allow for variations in the degree of differences across standards. To address this concern, I devise a second proxy based on the GAAP distance measure developed by Bae et al. (2008) and modified by Yu (2010). The Bae et al. (2008) measure is a summary score of how local GAAP differs from IFRS on 21 accounting dimensions. Bae et al. (2008) consider two accounting standards as similar when both rules comply with IFRS or when both rules follow local GAAP that are non-compliant with IFRS. It is unclear, however, that a pair of non-compliant local GAAP should be considered more similar to each other than a pair of local GAAP where only one complies with IFRS. I thus adopt the modification proposed by Yu (2010). Yu (2010) considers two non-compliant local GAAP to be similar only if the two 
countries are from the same legal origin. The result is a measure of accounting standards correlation across all country-pairs with a scale from 0 to 21 . I use an indicator variable COMP_HIGH equal to one if the accounting standards correlation measure is above the sample median and zero otherwise.

The coding of these two accounting standards correlation variables involves two steps. First, I construct a firm-year panel with an accounting standards variable. I begin with information from the "Accounting Standards Followed" field in Worldscope and follow the IFRS, U.S. GAAP and local GAAP coding based on Appendix A in Daske et al. (2009). As the Worldscope classification is prone to error, I augment the data with the hand-coded classifications from Daske et al. (2009). Second, for each firm-pair-year observation, I compare the accounting standards variables and construct the SAME and $C O M P_{-} H I G H$ correlation variables. Table 1, Panel $\mathrm{C}$ provides the breakdown of the accounting standards correlation variable. In the years prior to 2005, there are very few observations where the announcing and non-announcing firms are using the same accounting standards, with the few observations attributed to voluntary IFRS adoption or cross-listing. After mandatory adoption by the EU in 2005, the number of observations using the same accounting standards steadily increases. As a result, observations that use the same standards account for approximately $20 \%$ of the total sample. By construction, observations that use more correlated accounting standards account for approximately $50 \%$ of the total sample.

Departing from early information transfer studies that use announcing firm's abnormal return as a measure of potential information transfer, I follow recent literature and use unexpected earnings derived from consensus analyst forecasts. The use of this direct measure is advantageous, reducing the likelihood of inferring information transfer effects when they might actually be attributable to mis-specification of the returns generating model (Frost, 1985). Moreover, the unexpected earnings measure maps directly into the theoretical framework (i.e., $r_{1}-\mu_{1}$ in eqn. (7)). I measure unexpected earnings for the announcing firm $\left(U E_{1 t}\right)$ as the difference between the actual earnings per share (EPS) announced and 
the most recent median analyst EPS forecast before earnings announcement, scaled by the absolute value of the median EPS forecast. ${ }^{17}$ When evaluating the volume reaction, I replace $U E_{1 t}$ with the absolute value of $U E_{1 t}$ as volume tests are non-directional. $\gamma_{1}$, the coefficient on $U E_{1 t}$ captures the information transfer ERC (i.e., $\gamma$ in eqn. (7)) for firm-pairs using different accounting standards or having lower accounting standards correlation. The sum of $\gamma_{1}$ and $\gamma_{2}$ captures the information transfer ERC (i.e., $\gamma$ in eqn. (7)) for firm-pairs using the same accounting standards or having higher accounting standards correlation. My primary hypothesis predicts that $\gamma_{2}$ is positive, which suggests that, all else being equal, firm-pairs using the same accounting standards or having higher accounting standards correlation show greater information transfer effects.

I include several control variables that influence the magnitude of transnational information transfer. I categorize the control variables into four groups. The first group relates to the characteristics of the announcing firm (i.e., Firm1). It is commonly acknowledged that the potential for information transfer is generally greater for earnings announcements that embody new information for the announcer itself (i.e., have greater information content). More importantly, there is evidence that the information content of earnings announcement varies across countries (DeFond, Hung and Trezevant, 2007) and that IFRS adoption increases the information content of earnings announcements (Landsman, Maydew and Thornock, 2010). Thus, I include $C A R_{-}$1, the magnitude of Firm1's reaction to its own earnings announcement and predict the coefficient on $C A R_{-} 1$ to be positive. Hayn (1995) finds negative earnings are less informative. Thus, I include an indicator variable $L O S S_{-} 1$ equal to one if the reported EPS is negative, and zero otherwise. I expect the coefficient on $L O S S_{-} 1$ to be negative. I control for the size of Firm1, SIZE_ 1, measured

\footnotetext{
${ }^{17}$ Most studies use stock price as the deflator for unexpected earnings. I do not use stock price, as 1) changes in stock price due to macroeconomic conditions during the period may influence the results; and 2) conservative measurement practice in some countries may induce artificially low unexpected earnings deflated by price. For robustness, I run all of the tests using fiscal year end stock price as a deflator; the results are qualitatively the same.
} 
as the natural logarithm of the market value of equity at the end of fiscal year. I make no prediction with respect to the sign of the coefficient given there are conflicting arguments and evidence from prior literature. Han and Wild (2000) find information transfer effects are inversely related to firm size, for example, while Asthana and Mishra (2001) document a positive association. I include the reporting lag, $A N N L A G_{-} 1$, computed as the time from Firm1's fiscal year end to the earnings announcement reported by I/B/E/S. Based on findings in DeFond et al. (2007), I predict the coefficient on the reporting lag to be negative.

The second group of control variables relates to characteristics of the non-announcing firm (i.e., Firm2). I control for the size of Firm2, SIZE_2, measured as the natural logarithm of the market value of equity at the end of last calendar year. Prior research documents an inverse relation between the size of the non-announcing firm and the price response to an announcing firm's earnings surprise (e.g., Graham and King, 1996; Han and Wild, 2000). I therefore predict the coefficient on Firm2's size to be negative. I control for the amount of information production and dissemination by NUMEST_2, which is the number of analyst forecasts for Firm2 and predict a positive coefficient (De Fond et al., 2007). I control for $L E V_{-}$2, the ratio of Firm2's total debt to total assets, as differences in the level of debt financing across firms may affect the observed stock price reaction to significant events. Finally, I capture the differences in growth of Firm2 by including the book-to-market ratio, $B M_{-}$2, computed as the book value of equity divided by the market value of equity.

The third group of control variables is measured at the firm-pair level. I compute CORR, the correlation between the daily returns of Firm1 and Firm2 in the prior year to mitigate the concern that the empirical tests are capturing the co-movement of the returns of firms within the same industry (Longin and Solnik, 2001). Second, since Firm1 and Firm2 may have different fiscal year-end dates, I calculate FYOVLP as the number of overlapping days in the fiscal year. I predict both coefficients for the firm-pair controls to be positive. The fourth and last group of control variables includes indicator variables to control for country, industry, year and month fixed effects. 


\subsection{Empirical Results}

Table 2, Panel A reports descriptive statistics for all variables. On average, the announcing firms are larger than the non-announcing firms. Table 2, Panel B shows the pair-wise correlation between all variables used in the regression. The main variables of interest, SAME and COMP_HIGH, are not highly correlated with any other variables. These two proxies for correlation in accounting standards measurement error have a correlation of 0.48. $C A R_{1}$ and $C A R_{2}$ are positively correlated, consistent with the earlier assumption that information transfer effects are positive on average.

Table 3 presents the regression results from estimations of equations (12) and (13). First, I estimate two benchmark models as a baseline to confirm the validity of my sampling procedure. The domestic benchmark model is based on a separated constructed domestic sample. ${ }^{18}$ Results corroborate with extant literature that an information transfer effect exists: the coefficient of $U E_{1}$ (i.e., information transfer ERC) of 0.0059 is positive and significant $(\mathrm{t}$-stat $=2.75)$. This coefficient is larger but similar in magnitude to the coefficient of 0.0050 reported for U.S. domestic firms' information transfer effects from management earnings forecasts (Kim et al., 2008). The transnational benchmark model is estimated based on the global sample. In contrast to the domestic benchmark model, the information transfer effect is muted on average (i.e., the coefficient for $U E_{1}$ is insignificant).

The next four columns present the main results. In Model 1, I include the accounting standards correlation variables: the SAME indicator variable and also an interaction term $S A M E^{*} U E_{1}$. The coefficient for $U E_{1}, \gamma_{1}$, is insignificant, which implies no observable transnational information transfer effect when firms report under different accounting standards. The coefficient on the interaction, $S A M E^{*} U E_{1}, \gamma_{2}$, captures the difference in information transfer between firms using the same accounting standards and firms using

\footnotetext{
${ }^{18}$ For the same announcing firms described earlier, I choose a group of non-announcing firms in the same country. The non-announcing firms are not required to have non-zero foreign sales. All other sampling procedures remain constant.
} 
different accounting standards and it is positive and significant (t-stat $=1.67$ ). Therefore, the sum of the two coefficients, $\gamma_{1}+\gamma_{2}$, is the coefficient for the information transfer effect between two firms reporting under the same standards and it is positive and significant. Model 2 incorporates the control variables and the inferences remain the same. Signs of control variables are largely consistent with predictions. In Models 3 and 4, I replace the $S A M E$ indicator variable with the $C O M P_{-} H I G H$ indicator variable and the results are stronger. $\gamma_{2}$, the coefficient on the interaction $C O M P_{-} H I G H^{*} U E_{1}$, is positive and significant $(\mathrm{t}$-stat $=2.30$ and t-stat $=2.27)$ for Model 3 and Model 4 , respectively. The evidence is consistent with $H 1$ that the magnitude of information transfer is significantly greater when firms report under the same rather than different accounting standards.

Table 4 presents regression results from estimations of equations (12) and (13) with abnormal volume as the dependent variable. The overall inferences are similar to those of the price reaction tests but the statistical significance is weaker in magnitude. The two benchmark model analyses present evidence for a domestic information transfer effect but not a transnational information effect. In Models 1 and $2, \gamma_{2}$, the coefficient on the interaction $S A M E^{*}\left|U E_{1}\right|$, is directionally positive but statistically insignificant. In the next two columns, $\gamma_{2}$, the coefficient on the interaction $C O M P_{-} H I G H^{*}\left|U E_{1}\right|$, is positive and significant $(\mathrm{t}$-stat $=2.19$ and t-stat $=1.93)$ for Model 3 and Model 4, respectively. Overall, the results lend some support to H2 that non-announcing firms' volume reactions are stronger when the announcing firm reports under the same or more correlated standards.

Tables 5 and 6 report the results for the cross-sectional analyses for abnormal price and volume reactions, respectively. I divide the sample into various two-group partitions and perform a joint estimation of two separate equations (i.e., one for each group) using a seemingly unrelated regression (SUR) model. ${ }^{19}$ In the interest of brevity, I report only

\footnotetext{
${ }^{19}$ This is also referred to as a multivariate regression model, which is a special case of the seemingly unrelated regression model where the data matrices are group specific data sets on the same set of variables. See Chapter 10 of Greene (2008) for details of this estimation method.
} 
the results from using the $C O M P_{-} H I G H$ measure of accounting standards correlation. Results from using the SAME proxy are largely similar. The first two partitioning variables test H3 based on the announcer's home country characteristics. The legal enforcement partition is based on the rule of law variable for the year 2005 from Kaufmann, Kraay and Mastruzzi (2007) and the reporting incentives partition is based on the aggregate earnings management score from Leuz et al. (2003). ${ }^{20}$ Results from the price reaction tests are consistent with H3: the positive effect of a greater information transfer from using the same accounting standard is significant only for announcers domiciled in countries with strict legal enforcement and strong reporting incentives. The benefit is muted if the announcer domiciles in a lax enforcement or weak incentives country. The joint estimation procedure allows me to conduct statistical tests of the coefficients on the interaction term $\mathrm{COMP}_{-} H I G H^{*} U E_{1}$. The difference is both positive and significant (i.e., $\chi^{2}=9.45$ for the legal enforcement partition and $\chi^{2}=6.73$ for the reporting incentives partition). Results from the volume reaction tests are largely consistent, albeit weaker in magnitude. This evidence is consistent with the established view that merely adopting the same accounting standards does not necessarily change the properties of accounting reports.

The next two partitioning variables test $H_{4}$ based on firm-pair characteristics. The economic integration partition is based on whether the announcing firm and non-announcing firm are both EU member states. ${ }^{21}$ The price reaction test lends some support to the prediction that the information transfer benefits from accounting standards harmonization are stronger for firms with closer economic links. The volume reaction test does not provide evidence consistent with my predictions. The last partition relies on the assumption that overlap in firms' information environment facilitates the transmission and processing of the

\footnotetext{
${ }^{20}$ While there are overlaps in the two partitioning variables, differences exist for a few important countries. For example, Germany and Switzerland are categorized as strict legal enforcement but weak reporting incentives, while France is categorized as lax legal enforcement but strong reporting incentives.

${ }^{21}$ I include Norway and Switzerland in the EU classification although they are not official member states of the European Union.
} 
additional information signal. I partition the sample into two groups based on whether there is at least one overlapping sell-side analyst. The volume reaction test provides evidence consistent with the prediction, while the price reaction test is insignificant. The weaker results may be attributed to low test power, as only approximately $10 \%$ of the sample has overlapping sell-side analysts.

\section{Changes Analyses around the IFRS Mandate}

\section{$5.1 \quad$ Research Design}

My second set of tests pursues a different empirical strategy aiming to isolate the comparability effects (i.e., $\rho_{v}$, correlation between measurement errors) from the reporting

quality effects (i.e., $\sigma_{\eta_{1}}^{2}$, magnitude of measurement errors in the information signal) of accounting standards harmonization embedded in information transfer. Instead of pooling transnational information transfer effects from various countries over time, I focus on a group of announcing firms where the reporting quality effect is expected to be constant in the specific setting. Firms voluntarily adopted IFRS as early as in the 1990s for various reasons. In theory, the quality of the voluntary adopter's earnings signal (i.e., $\sigma_{\eta_{1}}^{2}$ ) does not change around the mandatory adoption period. Holding the quality of the earnings signals constant, I am able to isolate the comparability effect by evaluating the time-series changes in market reactions for a group of treatment firms (i.e., mandatory adopters) against a group of benchmark firms (i.e., non-adopters). The intuition for this difference-in-differences approach is that while both groups observe the same earnings signal; only the treatment group incurs a comparability benefit by moving to the same accountings standards.

I divide the firm-pair observations into four groups: treatment pre, treatment post, benchmark pre and benchmark post. I perform a joint estimation of four separate equations (i.e., one for each group) using a seemingly unrelated regression (SUR) model. Each regression equation takes the form:

$$
M k t \operatorname{Rea}_{2 t}=\alpha+\gamma U E_{1 t}+\sum \beta_{k} C t r l s_{k}+\varepsilon_{2 t}
$$


where MktRea stands for the abnormal price and volume reaction of the non-announcing firm. $U E_{1 t}$ and the vector of $C t r l s_{k}$ are identically defined as in equations (12) and (13).

The difference-in-differences analysis examines both univariate market reactions and $\gamma$, the earnings response coefficients. All else being equal, mandatory IFRS adoption will add comparability benefits only to firms in the treatment group. Therefore, I predict $\gamma$ will rise more for the treatment group following mandatory IFRS adoption than for the $\gamma$ of the benchmark group which continues to use local GAAP. The difference-in-differences analysis tests the prediction that $\left(\gamma_{\text {post }}^{\text {treatment }}-\gamma_{\text {pre }}^{\text {treatment }}\right)>\left(\gamma_{\text {post }}^{\text {benchmark }}-\gamma_{\text {pre }}^{\text {benchmark }}\right)$.

\subsection{Empirical Results}

Table 7, Panel A reports mean values of non-announcing firms' abnormal price reactions to earnings announcements by voluntary adopters for the period four years before and four years after mandatory IFRS adoption. For the treatment group, non-announcing firms' price reactions increased significantly from 0.0002 to 0.0036 ; the increase of 0.0034 is statistically significant $(\mathrm{t}$-stat $=5.05)$. Over the same time period, non-announcing firms in the benchmark group also experienced an increase from 0.0006 to 0.0008 , but this increase is statistically insignificant. The difference-in-differences of 0.0032 is statistically significant using t-tests that compare means of firm-pair-year changes across the two groups $(\mathrm{t}$-stat $=3.82)$. In addition, while there is an insignificant difference between the treatment and benchmark groups before mandatory IFRS adoption, after mandatory IFRS adoption, non-announcing firms' price reactions for the treatment group are significantly higher (by 0.0028) than for the benchmark group ( $\mathrm{t}$-stat $=3.93)$.

I compare $\gamma$, the information transfer ERC, in Table 7, Panel B. In the time-series comparisons, the $\chi^{2}$ test of equal coefficients shows that non-announcing firms in the treatment group experience an increase in $\gamma$ from -0.0019 in the pre-mandatory IFRS adoption period to 0.0027 in the post period. The difference is statistically significant at the $10 \%$ level $\left(\chi^{2}=3.11\right)$. For the benchmark group, in which the non-announcing firms continue to use local GAAP, there is no significant change in $\gamma$ before and after mandatory IFRS 
adoption. The difference in the time-series changes between the treatment group and control group is significant at the $5 \%$ level $\left(\chi^{2}=5.59\right)$. In the cross-sectional comparison, prior to mandatory IFRS adoption, there is no difference in the magnitude of information transfer between the treatment group and the benchmark group. This finding is consistent with my expectations since both groups are using local GAAP. After mandatory IFRS adoption, the treatment group that adopted IFRS exhibits greater information transfer effects than the benchmark group that continued to use local GAAP. The difference is statistically significant at the $1 \%$ level $\left(\chi^{2}=9.72\right)$.

Table 8 presents results for abnormal volume reaction as the dependent variable using the same research design. The evidence reveals similar trends as in the price reaction test. Together, the results are consistent with my hypothesis: holding the quality of the information signal constant, there is a significant increase in information transfer from voluntary adopters to mandatory adopters post-mandatory IFRS adoption. This effect is not present non-adopters. The evidence provides strong support that financial statement comparability effects, and not reporting quality effects, drive the greater information transfers post-mandatory IFRS adoption.

\section{Additional Analyses}

\subsection{Non-announcer's Unexpected Earnings as Dependent Variable}

I perform an alternative test that models Firm2's unexpected earnings as a function of Firm1's unexpected earnings, accounting standards correlation and control variables. The intuition is that Firm2's investors react to Firm1's unexpected earnings as this signal helps them to predict Firm2's unexpected earnings, which is their ultimate interest. I therefore attempt to provide some ex-post evidence that firm-pairs using the same accounting standards have a higher correlation in unexpected earnings than firm-pairs using different accounting standards. Table 9 presents some evidence consistent with this intuition. The coefficient on the interaction, $S A M E^{*} U E_{1}$, is positive and significant (t-stat $=2.43$ and t-stat $=2.53$, respectively) for Models 1 and 2 . 


\subsection{Effect of First Announcers}

Extant literature shows that the timing of announcements can influence inferences in information transfer studies. The information contained in the earnings announcement of the first reporter may be greater than subsequent reporting firms as it is more difficult to forecast the earnings for the first reporter in any fiscal year. Consequently, many studies focus on the effect of the first few announcers. A difficulty of this focus, however, is that the firms must have the same fiscal year-ends. In cross-country studies, imposing this requirement substantially reduces the sample size, as different countries have different and clustered fiscal year-end dates (e.g., March for Japan and June for Australia). Therefore, in my primary analysis, I do not rely on the effect of the first announcer, but rather focus on the industry leaders defined by size.

Nonetheless, to investigate this potential timing effect, I replicate Tables 3 and 4 based on a different sampling procedure for the announcing firms. First, I limit the global sample to December fiscal year-end firms. I subsequently rank these firms in each industry by market value and take the top $10 \%$ largest firms. Within this group, I choose the three earliest announcing firms and match with all possible non-announcing firms. Results based on this alternative sampling procedure are similar to my current analysis and consistent with the hypothesis. My results are thus robust to the first announcer effect.

\subsection{Importance of Economic Link}

I repeat the main analyses (Tables 3, 4, 7 and 8) with randomly selected non-announcing firms from different industries. The objective of this placebo test is to show that my results are not driven by higher price and volume reactions solely due to IFRS adoption. Untabulated results exhibit no similar patterns in information transfer for the placebo tests, thus confirming that the results presented are not mechanical. This evidence also highlights the importance of the underlying economic link in achieving the desired comparability benefits. 


\section{Conclusion}

This study investigates whether harmonization of accounting standards enhances financial statement comparability, defined as an increase in the correlation between measurement errors across two firms' information signals. I test this question jointly with predictions from a modified HV model, that this correlation increases a non-announcing firm's price and volume reactions to a foreign firm's earnings announcement. By linking comparability to the information transfer ERC, my study shows that accounting standards harmonization facilitates transnational information transfer, and suggests comparability as a direct mechanism.

My inferences are based on empirical results from two cross-border settings. First, employing a levels analysis for a global sample, I find that the non-announcing firms' abnormal price and volume reactions to an earnings announcement by the foreign firm are significantly higher if firms report under the same rather than different standards. Next, I use a difference-in-differences design around mandatory introduction of IFRS. I find that mandatory adopters experience a significant increase in market reactions to the release of earnings by voluntary adopters post-mandatory adoption. This increase is not observed for non-adopters over the same period. As the quality of voluntary adopters' earnings signals is likely to remain stable around mandatory adoption, my results are unlikely due to increases in reporting quality. 


\section{References}

Alves, P., Pope, P., Young, S., 2007. International information transfers: an analysis of European companies. Working paper, Lancaster University.

Armstrong, C., Barth, M., Jagolinzer, A., Riedl, E. J., 2010. Market reaction to the adoption of IFRS in Europe. The Accounting Review 85, 31-61.

Asthana, S.C., Mishra, B.K., 2001. The differential information hypothesis, firm size, and earnings information transfer: An empirical investigation. Journal of Business Research 53, $37-47$.

Atiase, R.K., 1985. Predisclosure information, firm capitalization, and security price behavior around earnings announcements. Journal of Accounting Research 23, 21-36.

Bae, K-H., Tan, H.P., Welker, M., 2008. International GAAP differences: The impact on foreign analysts. The Accounting Review 83, 593-628.

Baginski, S.P., 1987. Intraindustry information transfers associated with management forecasts of earnings. Journal of Accounting Research 25, 196-216.

Ball, R., Kothari, S.P., Robin, A., 2000. The effect of international institutional factors on properties of accounting earnings. Journal of Accounting and Economics 29, 1-51.

Ball, R., Robin, A., Wu, J.S., 2003. Incentives versus standards: properties of accounting income in four East Asian countries. Journal of Accounting and Economics 36, 235-270.

Bamber, L. 1987. Unexpected earnings, firm size, and trading volume around quarterly earnings announcements. The Accounting Review 62, 510-32.

Barth, M.E., Clinch, G., Shibano, T., 1999. International accounting harmonization and global equity markets. Journal of Accounting and Economics 26, 201-235.

Beaver, W.H., 1968. The information content of annual earnings announcements. Journal of Accounting Research 6, 67-92.

Beuselinck, C., Joos, P., Van der Meulen, S., 2007. International earnings comparability. Working Paper, Tilburg University.

Bradshaw, M.T., Miller, G.S., Serafeim, G., 2009. Accounting method heterogeneity and analysts' forecasts. Working paper, Boston College.

Brav, A., Heaton, J.B., 2002. Competing theories of financial anomalies. Review of Financial Studies 15, 575-606.

Burgstahler, D.C., Hail, L., Leuz, C., 2006. The Importance of reporting incentives: Earnings management in European private and public Firms. The Accounting Review 81, 983-1017.

Christensen, J., 2010. Accounting errors and errors of accounting. The Accounting Review $85,1827-1838$. 
Clinch, G.J., Sinclair, N.A., 1987. Intra-industry information releases: A recursive systems approach. Journal of Accounting and Economics 9, 89-106.

Daniel, K.D., Hirshleifer, D., Subrahmanyam, A., 1998. Investor psychology and security market under- and overreactions. Journal of Finance 53, 1839-1885.

Daniel, K.D., Hirshleifer, D., Subrahmanyam, A., 2001. Overconfidence, arbitrage, and equilibrium asset pricing. Journal of Finance 56, 921-965.

Daske, H., Hail, L., Leuz, C., Verdi, R.S., 2008. Mandatory IFRS reporting around the world: Early evidence on the economic consequences. Journal of Accounting Research 46, 1085-1142.

Daske, H., Hail, L., Leuz, C., Verdi, R.S., 2009. Adopting a label: Heterogeneity in the economic consequences of IFRS adoptions. Working Paper, University of Pennsylvania.

Dechow, P., Ge, W., Schrand, C., 2010. Understanding earnings quality: A review of the proxies, their determinants and their consequences. Journal of Accounting and Economics, forthcoming.

DeFond, M., Hu, X., Hung, M.Y., Li, S., 2009. The impact of IFRS Adoption on US mutual fund ownership: The role of comparability. Working paper, University of Southern California.

DeFond, M., Hung, M.Y., Trezevant, R., 2007. Investor protection and the information content of annual earnings announcement: International evidence. Journal of Accounting and Economics 43, 37-67.

De Franco, G., Kothari, S.P., Verdi R.S., 2010. The benefits of firm comparability. Working Paper, Massachusetts Institute of Technology.

DeLong, J.B., Shleifer, A., Summers, L.H., Waldmann, R.J.,1990. Noise trader risk in financial markets. Journal of Political Economy 98, 703-738.

Dye, R., 1990. Mandatory versus voluntary disclosures: The cases of financial and real externalities. The Accounting Review 65, 1-24.

Financial Accounting Standards Board, 2010. Concepts Statement No.8. Financial Accounting Standards Board.

Firth, M.A., 1976. The impact of earnings announcements on the share price behavior of similar type firms. Economic Journal 86, 296-306.

Firth, M.A., 1996. The transmission of corporate financial information across national borders and equity market linkages. Review of Accounting Studies 1, 309-337.

Fischer, P.E., Verrecchia, R.E., 2000. Reporting bias. The Accounting Review 75, 229-245.

Foster, G., 1981. Intra-industry information transfer associated with earnings releases. Journal of Accounting and Economics 3, 201-232. 
Freeman, R.N., 1987. The association between accounting earnings and security returns for large and small firms. Journal of Accounting and Economics 9, 195-228.

Freeman, R.N., Tse, S., 1992. An earnings prediction approach to examining intercompany information transfers. Journal of Accounting and Economics 15, 509-523.

Frost, C.A, 1995. Intraindustry information transfer: An analysis of research methods and additional evidence. Review of Quantitative Finance and Accounting 5, 111-126.

Graham, R.C., King, R.D., 1996. Industry information transfers: The effect of information environment. Journal of Business Finance and Accounting 23, 1289-1306.

Greene, W.H., 2008. Econometric Analysis, 6th edition. Pearson Prentice Hall, Upper Saddle River, NJ.

Han, J., Wild, J., Ramesh, K., 1989. Managers' earnings forecasts and intra-industry information transfers. Journal of Accounting and Economics 11, 3-33.

Han, J., Wild, J., 1990. Unexpected earnings and intra-industry information transfers: Further evidence. Journal of Accounting Research 28, 211-219.

Han, J., Wild, J., 2000. Predisclosure information, firm capitalization, and earnings information transfers . Journal of Business Research 49, 273-288.

Hayn, C., 1995. The information content of losses. Journal of Accounting and Economics 20, 125-153.

Hirshleifer, D., Lim, S.S., Teoh, S.H., 2009. Driven to distraction: Extraneous events and underreaction to earnings news. Journal of Finance 64, 2289-2325.

Hirshleifer, D., Teoh, S.H., 2003. Limited attention, information disclosure, and financial reporting. Journal of Accounting and Economics 36, 337-386.

Holthausen, R.W., Verrecchia, R.E., 1988. The effect of sequential information releases on the variance of price changes in an intertemporal multi-asset market. Journal of Accounting Research 26, 82-106.

Hong, H., Stein, J.C., 1999. A unified theory of underreaction, momentum trading and overreaction in asset markets, Journal of Finance 54, 2143-2184.

International Accounting Standards Board, 2010. The Conceptual Framework for Financial Reporting. International Accounting Standards Board.

Kaufmann, D., Kraay, A., Mastruzzi, M., 2007. Governance Matters VI: Aggregate and Individual Governance Indicators 1996-2006. Washington, DC: The World Bank.

Kim, O., Verrecchia, R.E., 1991. Trading volume and price reaction to public announcements. Journal of Accounting Research 29, 302-321. 
Kim, Y., Lacina, M., Park, M., 2008. Positive and negative information transfers from management earnings forecasts. Journal of Accounting Research 46, 885-908.

Landsman, W., Maydew, E., Thornock, J., 2010. The information content of annual earnings announcements and mandatory adoption of IFRS. Working paper, University of North Carolina at Chapel Hill.

Lang, L.H.P., Stulz, R.M., 1992. Contagion and competitive intra-industry effects of bankruptcy announcements: An empirical analysis. Journal of Financial Economics 32, 45-60.

Lang, M.H., Maffett, M., Owens, E., 2010. Earnings comovement and accounting comparability: the effects of mandatory IFRS adoption. Working paper, University of North Carolina at Chapel Hill.

Laux, P., Starks, L.T., Yoon, P.S., 1998. The relative importance of competition and contagion in intra-industry information transfers: An investigation of dividend announcements. Financial Management 27, 5-16.

Lehavy, R., Sloan, R.G., 2008. Investor recognition and stock returns. Review of Accounting Studies 13, 327-361.

Leuz, C., Nanda, D., Wysocki, P.D., 2003. Earnings management and investor protection: an international comparison. Journal of Financial Economics 69, 505-527.

Libby, R., Libby, P.A., Short, D.G., 2009. Financial Accounting, 6th edition. McGraw-Hill/Irwin, New York, NY.

Longin, F., Solnik, B., 2001. Extreme correlation of international equity markets. Journal of Finance 56, 649-676.

Merton, R.C., 1987. A simple model of capital market equilibrium with incomplete information. Journal of Finance 42, 483-510.

Pyo, Y., Lustgarten, S., 1990. Differential intra-industry information transfer associated with management earnings forecasts. Journal of Accounting and Economics 13, 365-379.

Ramnath, S., 2002. Investor and analyst reactions to earnings announcements of related firms: An empirical analysis. Journal of Accounting Research 40, 1351-1376.

Shleifer, A., Vishny, R.W., 1997. The limits of arbitrage. Journal of Finance 52, 35-55.

Street D.L., Gray S.J., 2001. Observance of International Accounting Standards: Factors explaining non-compliance by companies referring to the use of IAS. ACCA Research Monograph.

Tan, H., Wang, S., Welker, M., 2009. Foreign analyst following and forecast accuracy around mandatory IFRS adoptions. Working paper, University of Waterloo. 
Thomas, J., Zhang, F., 2008. Overreaction to intra-industry information transfers? Journal of Accounting Research 46, 909-949.

Wu, J.S., Zhang, I., 2010. Accounting integration and comparability: Evidence from relative performance evaluation around IFRS adoption. Working paper, University of Rochester.

Yu, G., 2010. Accounting standards and international portfolio holdings: Analysis of cross-border holdings following mandatory adoption of IFRS. Working paper, Harvard University.

Zeff, S.A., 2007. Some obstacles to global financial reporting comparability and convergence at a high level of quality. The British Accounting Review 39, 290-302. 


\section{APPENDIX A}

In this appendix, I briefly discuss another approach that could result in accounting standards measurement error correlation playing a role at Firm1's report date. The key assumption in this approach is there is a real externality from reporting, i.e., Firm2 will alter its distribution of cash flows as a result of Firm1's report (Dye, 1990). The intuition is that if the measurement errors are more correlated, then Firm2's manager can better infer Firm1's underlying cash flows and competitive positions from Firm1's report. As a result, Firm2's manager will more likely to alter Firm2's operations in response to Firm1's report. Consequently, there will be an immediate value effect reflected in Firm2's equilibrium pricing at the announcement of Firm1's report. This change results from altering the actual distributions of Firm2's cash flows, not just investors' perceptions of these cash flows. 
FIGURE 1

Timeline of Events and Summary of Theoretical Characterization

$\underline{\text { Panel A }}$

Timeline

Firm2's Current

Report Already Released

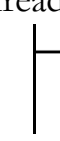

$t=1$

Firm1's Earnings Report

$$
\tilde{r}_{1}=r_{1}
$$

$\mathrm{t}=2$

Firm2's Next Earnings Report $\tilde{r}_{2}=r_{2}$

\section{Panel B}

HV Model:

Rational Expectations

$$
\begin{aligned}
P_{2}^{t=0} & =E\left[\tilde{V}_{2}\right] \\
& =\mu_{2}
\end{aligned}
$$

$$
P_{2}^{t=0}=E\left[\tilde{V}_{2}\right] \quad P_{2}^{t=1}=E\left[\tilde{V}_{2} \mid \tilde{r}_{1}=r_{1}\right]
$$

$$
P_{2}^{t=2}=E\left[\tilde{V}_{2} \mid \tilde{r}_{2}=r_{2}\right]
$$

when $r_{2}$ is realized

Assumption 2:

Investors use $r_{1}$ to predict $\tilde{P}_{2}^{T=2}$

$$
P_{2}^{t=0}=E\left[\tilde{V}_{2}\right]
$$

$$
P_{2}^{t=1}=E\left[\tilde{P}_{2}^{t=2} \mid \tilde{r}_{1}=r_{1}\right]
$$

$$
P_{2}^{t=2}=E\left[\tilde{V}_{2} \mid \tilde{r}_{2}=r_{2}\right]
$$

$$
+\frac{\sigma_{v_{2}}^{2}\left(\sigma_{v_{1}}^{2}+\sigma_{\eta_{1}}^{2}\right)-\rho_{v} \sigma_{v_{1}} \sigma_{v_{2}}\left(\rho_{v} \sigma_{v_{1}} \sigma_{v_{2}}+\rho_{\eta} \sigma_{\eta_{1}} \sigma_{\eta_{2}}\right)}{\left(\sigma_{v_{1}}^{2}+\sigma_{\eta_{1}}^{2}\right)\left(\sigma_{v_{2}}^{2}+\sigma_{\eta_{2}}^{2}\right)-\left(\rho_{v} \sigma_{v_{1}} \sigma_{v_{2}}+\rho_{\eta} \sigma_{\eta_{1}} \sigma_{\eta_{2}}\right)^{2}}\left(r_{2}-\mu_{2}\right)
$$

\section{Panel D}

Modified HV Model:

$$
\begin{aligned}
P_{2}^{t=0}=E\left[\tilde{V}_{2}\right] \quad P_{2}^{t=1} & =E\left[\tilde{P}_{2}^{t=2} \mid \tilde{r}_{1}=r_{1}\right] \\
& =\mu_{2}
\end{aligned}
$$




\section{TABLE 1}

\section{Sample Composition by Country, Year and Industry}

Table 1 presents the sample composition by announcements, firms, and firm-pair-year observations. The levels analyses sample comprises a maximum of 26,349 firm-pair-year observations from 575 earnings announcements between 2001 and 2008 with sufficient financial data from Worldscope, price and volume data from Datastream, and analyst forecasts data from I/B/E/S. Panel A reports the distribution of announcements, unique firms and firm-pairyear observations by country for the announcing firm. Panel B reports the distribution of unique firms and firm-pairyear observations by country for the non-announcing firms. Panel C reports the distribution of firm-pair-year observations by year and industry and two indicator variables for accounting standards correlation. Same Standards is an indicator variable equal to one when the announcing and non-announcing firm-pair use the same accounting standard and zero otherwise. Std Comp - High is an indicator variable equal to one if the accounting standard correlation measure is above the median and zero otherwise. The accounting standard correlation measure is calculated based on the GAAP distance measure developed by Bae et al. (2008) and modified by Yu (2010). Accounting standards are coded based on the "accounting standards followed" field in Worldscope (field 07536) and augmented by corrections from the extensive manual review described in Daske et al. (2009). The changes analyses sample comprises 20,997 firm-pair-year observations from 834 earnings announcements between 2001 and 2008 with sufficient data. All announcing firms in this sample are voluntary IFRS adopter. The sample is divided into two groups: (1) firm-pair observations in which the non-announcing firms are mandatory IFRS adopters (i.e., treatment group) and (2) firm-pair observations in which the non-announcing firms are non-IFRS adopters (i.e., benchmark group). Panel A reports the distribution of announcements, unique firms and firm-pair-year observations by country for the announcing firm. Panel B reports the distribution of unique firms and firm-pair-year observations by country for the non-announcing firms. Panel $\mathrm{C}$ reports the distribution of firm-pair-year observations for the entire sample and the treatment group by year and industry.

Panel A: Distribution of Announcements, Announcing Firms and Firm-Pair-Year Observations

\begin{tabular}{|c|c|c|c|c|c|c|c|c|c|c|c|c|}
\hline \multirow[b]{3}{*}{ Country } & \multicolumn{6}{|c|}{ Levels Analyses Sample } & \multicolumn{6}{|c|}{ Changes Analyses Sample } \\
\hline & \multicolumn{2}{|c|}{ Announcements } & \multicolumn{2}{|c|}{ Unique Firms } & \multicolumn{2}{|c|}{ Firm-Pair-Year } & \multicolumn{2}{|c|}{ Announcements } & \multicolumn{2}{|c|}{ Unique Firms } & \multicolumn{2}{|c|}{ Firm-Pair-Year } \\
\hline & $\#$ & $\%$ & $\#$ & $\%$ & $\#$ & $\%$ & $\#$ & $\%$ & $\#$ & $\%$ & \# & $\%$ \\
\hline Australia & 9 & $1.6 \%$ & 2 & $1.5 \%$ & 99 & $0.4 \%$ & 10 & $1.2 \%$ & 2 & $1.4 \%$ & 240 & $1.1 \%$ \\
\hline Austria & - & - & - & - & - & - & 17 & $2.0 \%$ & 3 & $2.1 \%$ & 150 & $0.7 \%$ \\
\hline Belgium & 8 & $1.4 \%$ & 1 & $0.7 \%$ & 71 & $0.3 \%$ & 42 & $5.0 \%$ & 7 & $4.8 \%$ & 525 & $2.5 \%$ \\
\hline Canada & 6 & $1.0 \%$ & 4 & $2.9 \%$ & 253 & $1.0 \%$ & - & - & - & - & - & - \\
\hline China & 7 & $1.2 \%$ & 7 & $5.1 \%$ & 71 & $0.3 \%$ & - & - & - & - & - & - \\
\hline Czech Republic & - & - & - & - & - & - & 7 & $0.8 \%$ & 1 & $0.7 \%$ & 34 & $0.2 \%$ \\
\hline Denmark & 1 & $0.2 \%$ & 1 & $0.7 \%$ & 12 & $0.0 \%$ & 33 & $4.0 \%$ & 6 & $4.1 \%$ & 1,302 & $6.2 \%$ \\
\hline Finland & 21 & $3.7 \%$ & 3 & $2.2 \%$ & 2,495 & $9.5 \%$ & 46 & $5.5 \%$ & 8 & $5.5 \%$ & 2,287 & $10.9 \%$ \\
\hline France & 93 & $16.2 \%$ & 18 & $13.2 \%$ & 3,951 & $15.0 \%$ & 84 & $10.1 \%$ & 15 & $10.3 \%$ & 3,202 & $15.2 \%$ \\
\hline Germany & 53 & $9.2 \%$ & 10 & $7.4 \%$ & 5,189 & $19.7 \%$ & 193 & $23.1 \%$ & 35 & $24.1 \%$ & 4,025 & $19.2 \%$ \\
\hline Greece & - & - & - & - & - & - & 12 & $1.4 \%$ & 2 & $1.4 \%$ & 316 & $1.5 \%$ \\
\hline Hong Kong & 16 & $2.8 \%$ & 4 & $2.9 \%$ & 222 & $0.8 \%$ & 38 & $4.6 \%$ & 6 & $4.1 \%$ & 578 & $2.8 \%$ \\
\hline Hungry & - & - & - & - & - & - & 17 & $2.0 \%$ & 3 & $2.1 \%$ & 224 & $1.1 \%$ \\
\hline India & 5 & $0.9 \%$ & 4 & $2.9 \%$ & 528 & $2.0 \%$ & - & - & - & - & - & - \\
\hline Ireland & 3 & $0.5 \%$ & 1 & $0.7 \%$ & 241 & $0.9 \%$ & - & - & - & - & - & - \\
\hline Italy & 1 & $0.2 \%$ & 1 & $0.7 \%$ & 68 & $0.3 \%$ & 67 & $8.0 \%$ & 11 & $7.6 \%$ & 1,143 & $5.4 \%$ \\
\hline Japan & 128 & $22.3 \%$ & 32 & $23.5 \%$ & 4,875 & $18.5 \%$ & - & - & - & - & - & - \\
\hline Korea & 16 & $2.8 \%$ & 4 & $2.9 \%$ & 313 & $1.2 \%$ & - & - & - & - & - & - \\
\hline Mexico & 10 & $1.7 \%$ & 2 & $1.5 \%$ & 395 & $1.5 \%$ & - & - & - & - & - & - \\
\hline Netherlands & 35 & $6.1 \%$ & 8 & $5.9 \%$ & 805 & $3.1 \%$ & 19 & $2.3 \%$ & 4 & $2.8 \%$ & 288 & $1.4 \%$ \\
\hline Norway & 7 & $1.2 \%$ & 2 & $1.5 \%$ & 275 & $1.0 \%$ & - & - & - & - & - & - \\
\hline Poland & - & - & - & - & - & - & 18 & $2.2 \%$ & 3 & $2.1 \%$ & 306 & $1.5 \%$ \\
\hline Portugal & - & - & - & - & - & - & 9 & $1.1 \%$ & 2 & $1.4 \%$ & 95 & $0.5 \%$ \\
\hline Russia & 2 & $0.3 \%$ & 1 & $0.7 \%$ & 39 & $0.1 \%$ & - & - & - & - & - & - \\
\hline Spain & 5 & $0.9 \%$ & 2 & $1.5 \%$ & 225 & $0.9 \%$ & - & - & - & - & - & - \\
\hline South Africa & - & - & - & - & - & - & 56 & $6.7 \%$ & 10 & $6.9 \%$ & 1,316 & $6.3 \%$ \\
\hline Sweden & 9 & $1.6 \%$ & 3 & $2.2 \%$ & 283 & $1.1 \%$ & 23 & $2.8 \%$ & 4 & $2.8 \%$ & 604 & $2.9 \%$ \\
\hline Switzerland & 24 & $4.2 \%$ & 4 & $2.9 \%$ & 1,788 & $6.8 \%$ & 143 & $17.1 \%$ & 23 & $15.9 \%$ & 4,362 & $20.8 \%$ \\
\hline Taiwan & 3 & $0.5 \%$ & 1 & $0.7 \%$ & 11 & $0.0 \%$ & - & - & - & - & - & - \\
\hline United Kingdom & 113 & $19.7 \%$ & 21 & $15.4 \%$ & 4,140 & $15.7 \%$ & - & - & - & - & - & - \\
\hline Total & 575 & $100.0 \%$ & 136 & $100.0 \%$ & 26,349 & $100.0 \%$ & 834 & $100.0 \%$ & 145 & $100.0 \%$ & 20,997 & $100.0 \%$ \\
\hline
\end{tabular}


TABLE 1 (Continued)

Sample Composition by Country, Year and Industry

Panel B: Distribution of Non-Announcing Firms and Firm-Pair-Year Observations

\begin{tabular}{|c|c|c|c|c|c|c|c|c|}
\hline \multirow[b]{2}{*}{ Country } & \multicolumn{4}{|c|}{ Levels Analyses Sample } & \multicolumn{4}{|c|}{ Changes Analyses Sample } \\
\hline & $\begin{array}{l}\text { Unique } \\
\text { Firms }\end{array}$ & $\%$ & $\begin{array}{l}\text { Firm-Pair- } \\
\text { Year Obs }\end{array}$ & $\%$ & $\begin{array}{l}\text { Unique } \\
\text { Firms }\end{array}$ & $\%$ & $\begin{array}{c}\text { Firm-Pair- } \\
\text { Year Obs }\end{array}$ & $\%$ \\
\hline Argentina & 6 & $0.1 \%$ & 29 & $0.1 \%$ & 3 & $0.2 \%$ & 31 & $0.1 \%$ \\
\hline Australia & 211 & $4.7 \%$ & 1,040 & $3.9 \%$ & 58 & $3.8 \%$ & 310 & $1.5 \%$ \\
\hline Austria & 40 & $0.9 \%$ & 233 & $0.9 \%$ & 3 & $0.2 \%$ & 47 & $0.2 \%$ \\
\hline Belgium & 57 & $1.3 \%$ & 492 & $1.9 \%$ & 16 & $1.1 \%$ & 276 & $1.3 \%$ \\
\hline Brazil & 14 & $0.3 \%$ & 91 & $0.3 \%$ & 5 & $0.3 \%$ & 87 & $0.4 \%$ \\
\hline Canada & 328 & $7.3 \%$ & 1,975 & $7.5 \%$ & 120 & $7.9 \%$ & 1,364 & $6.5 \%$ \\
\hline Chile & 3 & $0.1 \%$ & 9 & $0.0 \%$ & 1 & $0.1 \%$ & 10 & $0.0 \%$ \\
\hline China & 89 & $2.0 \%$ & 368 & $1.4 \%$ & 16 & $1.1 \%$ & 217 & $1.0 \%$ \\
\hline Colombia & - & - & - & - & 1 & $0.1 \%$ & 1 & $0.0 \%$ \\
\hline Czech Republic & 1 & $0.0 \%$ & 13 & $0.0 \%$ & 1 & $0.1 \%$ & 43 & $0.2 \%$ \\
\hline Denmark & 49 & $1.1 \%$ & 447 & $1.7 \%$ & 26 & $1.7 \%$ & 440 & $2.1 \%$ \\
\hline Egypt & 3 & $0.1 \%$ & 15 & $0.1 \%$ & 1 & $0.1 \%$ & 18 & $0.1 \%$ \\
\hline Finland & 76 & $1.7 \%$ & 447 & $1.7 \%$ & 33 & $2.2 \%$ & 318 & $1.5 \%$ \\
\hline France & 318 & $7.1 \%$ & 2,364 & $9.0 \%$ & 162 & $10.7 \%$ & 2,851 & $13.6 \%$ \\
\hline Germany & 272 & $6.1 \%$ & 1,521 & $5.8 \%$ & 59 & $3.9 \%$ & 930 & $4.4 \%$ \\
\hline Greece & 62 & $1.4 \%$ & 304 & $1.2 \%$ & 16 & $1.1 \%$ & 217 & $1.0 \%$ \\
\hline Hong Kong & 274 & $6.1 \%$ & 1,635 & $6.2 \%$ & 105 & $7.0 \%$ & 1,725 & $8.2 \%$ \\
\hline Hungry & 9 & $0.2 \%$ & 62 & $0.2 \%$ & - & - & - & - \\
\hline India & 87 & $1.9 \%$ & 306 & $1.2 \%$ & 13 & $0.9 \%$ & 103 & $0.5 \%$ \\
\hline Indonesia & 20 & $0.4 \%$ & 142 & $0.5 \%$ & 9 & $0.6 \%$ & 284 & $1.4 \%$ \\
\hline Ireland & 43 & $1.0 \%$ & 278 & $1.1 \%$ & 22 & $1.5 \%$ & 290 & $1.4 \%$ \\
\hline Israel & 56 & $1.3 \%$ & 389 & $1.5 \%$ & 16 & $1.1 \%$ & 195 & $0.9 \%$ \\
\hline Italy & 132 & $3.0 \%$ & 1,019 & $3.9 \%$ & 16 & $1.1 \%$ & 323 & $1.5 \%$ \\
\hline Japan & 172 & $3.9 \%$ & 414 & $1.6 \%$ & 25 & $1.7 \%$ & 204 & $1.0 \%$ \\
\hline Korea & 62 & $1.4 \%$ & 275 & $1.0 \%$ & 25 & $1.7 \%$ & 330 & $1.6 \%$ \\
\hline Luxembourg & 2 & $0.0 \%$ & 2 & $0.0 \%$ & 2 & $0.1 \%$ & 5 & $0.0 \%$ \\
\hline Malaysia & 132 & $3.0 \%$ & 612 & $2.3 \%$ & 50 & $3.3 \%$ & 425 & $2.0 \%$ \\
\hline Mexico & 25 & $0.6 \%$ & 122 & $0.5 \%$ & 13 & $0.9 \%$ & 106 & $0.5 \%$ \\
\hline Netherlands & 110 & $2.5 \%$ & 845 & $3.2 \%$ & 59 & $3.9 \%$ & 820 & $3.9 \%$ \\
\hline New Zealand & 28 & $0.6 \%$ & 141 & $0.5 \%$ & 1 & $0.1 \%$ & 2 & $0.0 \%$ \\
\hline Norway & 85 & $1.9 \%$ & 559 & $2.1 \%$ & 37 & $2.5 \%$ & 343 & $1.6 \%$ \\
\hline Pakistan & 1 & $0.0 \%$ & 9 & $0.0 \%$ & - & - & - & - \\
\hline Peru & 1 & $0.0 \%$ & 8 & $0.0 \%$ & - & - & - & - \\
\hline Philippines & 10 & $0.2 \%$ & 74 & $0.3 \%$ & 5 & $0.3 \%$ & 162 & $0.8 \%$ \\
\hline Poland & 20 & $0.4 \%$ & 86 & $0.3 \%$ & 3 & $0.2 \%$ & 64 & $0.3 \%$ \\
\hline Portugal & 28 & $0.6 \%$ & 276 & $1.0 \%$ & 11 & $0.7 \%$ & 261 & $1.2 \%$ \\
\hline Russia & 13 & $0.3 \%$ & 69 & $0.3 \%$ & 2 & $0.1 \%$ & 45 & $0.2 \%$ \\
\hline Singapore & 214 & $4.8 \%$ & 1,184 & $4.5 \%$ & 76 & $5.0 \%$ & 704 & $3.4 \%$ \\
\hline South Africa & 60 & $1.3 \%$ & 306 & $1.2 \%$ & 13 & $0.9 \%$ & 95 & $0.5 \%$ \\
\hline Spain & 78 & $1.7 \%$ & 548 & $2.1 \%$ & 42 & $2.8 \%$ & 560 & $2.7 \%$ \\
\hline Sweden & 114 & $2.6 \%$ & 717 & $2.7 \%$ & 61 & $4.0 \%$ & 515 & $2.5 \%$ \\
\hline Switzerland & 104 & $2.3 \%$ & 922 & $3.5 \%$ & 28 & $1.9 \%$ & 445 & $2.1 \%$ \\
\hline Taiwan & 208 & $4.7 \%$ & 1,621 & $6.2 \%$ & 99 & $6.6 \%$ & 2,301 & $11.0 \%$ \\
\hline Thailand & 38 & $0.9 \%$ & 281 & $1.1 \%$ & 17 & $1.1 \%$ & 238 & $1.1 \%$ \\
\hline Turkey & 36 & $0.8 \%$ & 234 & $0.9 \%$ & 2 & $0.1 \%$ & 11 & $0.1 \%$ \\
\hline United Kingdom & 775 & $17.3 \%$ & 3,864 & $14.7 \%$ & 237 & $15.7 \%$ & 3,281 & $15.6 \%$ \\
\hline Venezuela & 1 & $0.0 \%$ & 1 & $0.0 \%$ & - & - & - & - \\
\hline Total & 4,467 & $100.0 \%$ & 26,349 & $100.0 \%$ & 1,510 & $100.0 \%$ & 20,997 & $100.0 \%$ \\
\hline
\end{tabular}


TABLE 1 (Continued)

Sample Composition by Country, Year and Industry

Panel C: Distribution of Firm-Pair-Year Observations by Year, Industry and Accounting Standards

\begin{tabular}{|c|c|c|c|c|c|c|c|c|c|c|c|}
\hline & & \multicolumn{6}{|c|}{ Levels Analyses Sample } & \multicolumn{4}{|c|}{ Changes Analyses Sample } \\
\hline & & \multirow{3}{*}{$\begin{array}{l}\text { Firm-Pair- } \\
\text { Year Obs }\end{array}$} & \multirow[b]{3}{*}{$\%$} & \multicolumn{4}{|c|}{ Non-Announcers } & \multirow{3}{*}{$\begin{array}{l}\text { Firm-Pair- } \\
\text { Year Obs }\end{array}$} & \multirow[b]{3}{*}{$\%$} & \multirow{2}{*}{\multicolumn{2}{|c|}{$\begin{array}{l}\text { Non-Announcers } \\
\text { Mandatory Adopter }\end{array}$}} \\
\hline & & & & \multicolumn{2}{|c|}{ Same Standards } & \multicolumn{2}{|c|}{ Std Comp - High } & & & & \\
\hline & & & & Obs & $\%$ & Obs & $\%$ & & & Obs & $\%$ \\
\hline \multicolumn{12}{|c|}{ Year } \\
\hline 200 & & 2,730 & $10.4 \%$ & 93 & $3.4 \%$ & 957 & $35.1 \%$ & 1,202 & $5.7 \%$ & 793 & $66.0 \%$ \\
\hline 200 & & 2,952 & $11.2 \%$ & 108 & $3.7 \%$ & 1,177 & $39.9 \%$ & 1,446 & $6.9 \%$ & 988 & $68.3 \%$ \\
\hline 200 & & 3,042 & $11.5 \%$ & 127 & $4.2 \%$ & 1,255 & $41.3 \%$ & 2,292 & $10.9 \%$ & 1,429 & $62.3 \%$ \\
\hline 200 & & 3,247 & $12.3 \%$ & 151 & $4.7 \%$ & 1,338 & $41.2 \%$ & 4,042 & $19.3 \%$ & 2,346 & $58.0 \%$ \\
\hline 200 & & 3,335 & $12.7 \%$ & 862 & $25.8 \%$ & 1,886 & $56.6 \%$ & 3,816 & $18.2 \%$ & 1,988 & $52.1 \%$ \\
\hline 200 & & 3,835 & $14.6 \%$ & 1,144 & $29.8 \%$ & 2,292 & $59.8 \%$ & 2,834 & $13.5 \%$ & 1,581 & $55.8 \%$ \\
\hline 200 & & 3,448 & $13.1 \%$ & 1,262 & $36.6 \%$ & 2,251 & $65.3 \%$ & 3,090 & $14.7 \%$ & 1,863 & $60.3 \%$ \\
\hline 200 & & 3,760 & $14.3 \%$ & 1,436 & $38.2 \%$ & 2,352 & $62.6 \%$ & 2,275 & $10.8 \%$ & 1,334 & $58.6 \%$ \\
\hline Tot & & 26,349 & $100.0 \%$ & 5,183 & $19.7 \%$ & 13,508 & $51.3 \%$ & 20,997 & $100.0 \%$ & 12,322 & $58.7 \%$ \\
\hline \multicolumn{12}{|c|}{ FF30 Industry } \\
\hline 1 & Food & 1,195 & $4.5 \%$ & 447 & $37.4 \%$ & 719 & $60.2 \%$ & 1,182 & $5.6 \%$ & 661 & $55.9 \%$ \\
\hline 2 & Beer & 189 & $0.7 \%$ & 60 & $31.7 \%$ & 155 & $82.0 \%$ & 68 & $0.3 \%$ & 45 & $66.2 \%$ \\
\hline 4 & Games & 614 & $2.3 \%$ & 24 & $3.9 \%$ & 391 & $63.7 \%$ & 116 & $0.6 \%$ & 26 & $22.4 \%$ \\
\hline 5 & Books & 398 & $1.5 \%$ & 145 & $36.4 \%$ & 305 & $76.6 \%$ & 67 & $0.3 \%$ & 61 & $91.0 \%$ \\
\hline 6 & Hshld & 790 & $3.0 \%$ & 273 & $34.6 \%$ & 452 & $57.2 \%$ & 289 & $1.4 \%$ & 159 & $55.0 \%$ \\
\hline 7 & Clths & 219 & $0.8 \%$ & 55 & $25.1 \%$ & 89 & $40.6 \%$ & 84 & $0.4 \%$ & 29 & $34.5 \%$ \\
\hline 8 & Hlth & 1,852 & $7.0 \%$ & 766 & $41.4 \%$ & 1,092 & $59.0 \%$ & 1,947 & $9.3 \%$ & 1,316 & $67.6 \%$ \\
\hline 9 & Chems & 684 & $2.6 \%$ & 162 & $23.7 \%$ & 353 & $51.6 \%$ & 1,165 & $5.5 \%$ & 769 & $66.0 \%$ \\
\hline 10 & Txtls & 150 & $0.6 \%$ & 0 & $0.0 \%$ & 72 & $48.0 \%$ & - & - & - & - \\
\hline 11 & Cnstr & 1,925 & $7.3 \%$ & 553 & $28.7 \%$ & 996 & $51.7 \%$ & 1,342 & $6.4 \%$ & 969 & $72.2 \%$ \\
\hline 12 & Steel & 587 & $2.2 \%$ & 7 & $1.2 \%$ & 270 & $46.0 \%$ & 428 & $2.0 \%$ & 261 & $61.0 \%$ \\
\hline 13 & FabPr & 866 & $3.3 \%$ & 25 & $2.9 \%$ & 458 & $52.9 \%$ & 524 & $2.5 \%$ & 321 & $61.3 \%$ \\
\hline 14 & ElcEq & 274 & $1.0 \%$ & 12 & $4.4 \%$ & 135 & $49.3 \%$ & - & - & - & - \\
\hline 15 & Autos & 423 & $1.6 \%$ & 41 & $9.7 \%$ & 156 & $36.9 \%$ & 676 & $3.2 \%$ & 318 & $47.0 \%$ \\
\hline 16 & Carry & 236 & $0.9 \%$ & 48 & $20.3 \%$ & 189 & $80.1 \%$ & 35 & $0.2 \%$ & 23 & $65.7 \%$ \\
\hline 17 & Mines & 486 & $1.8 \%$ & 86 & $17.7 \%$ & 448 & $92.2 \%$ & 349 & $1.7 \%$ & 165 & $47.3 \%$ \\
\hline 19 & Oil & 1,302 & $4.9 \%$ & 377 & $29.0 \%$ & 877 & $67.4 \%$ & 751 & $3.6 \%$ & 434 & $57.8 \%$ \\
\hline 21 & Telcm & 503 & $1.9 \%$ & 120 & $23.9 \%$ & 315 & $62.6 \%$ & 630 & $3.0 \%$ & 424 & $67.3 \%$ \\
\hline 22 & Servs & 4,061 & $15.4 \%$ & 102 & $2.5 \%$ & 1,426 & $35.1 \%$ & 2,700 & $12.9 \%$ & 2,055 & $76.1 \%$ \\
\hline 23 & BusEq & 5,584 & $21.2 \%$ & 1,030 & $18.4 \%$ & 2,560 & $45.8 \%$ & 4,547 & $21.7 \%$ & 1,901 & $41.8 \%$ \\
\hline 24 & Paper & 751 & $2.9 \%$ & 239 & $31.8 \%$ & 305 & $40.6 \%$ & 328 & $1.6 \%$ & 185 & $56.4 \%$ \\
\hline 25 & Trans & 817 & $3.1 \%$ & 202 & $24.7 \%$ & 539 & $66.0 \%$ & 1,227 & $5.8 \%$ & 677 & $55.2 \%$ \\
\hline 26 & Whlsl & 1,250 & $4.7 \%$ & 161 & $12.9 \%$ & 502 & $40.2 \%$ & 2,232 & $10.6 \%$ & 1,337 & $59.9 \%$ \\
\hline 27 & Rtail & 716 & $2.7 \%$ & 145 & $20.3 \%$ & 438 & $61.2 \%$ & 230 & $1.1 \%$ & 148 & $64.3 \%$ \\
\hline 28 & Meals & 477 & $1.8 \%$ & 103 & $21.6 \%$ & 266 & $55.8 \%$ & 80 & $0.4 \%$ & 38 & $47.5 \%$ \\
\hline \multicolumn{2}{|c|}{ Total } & 26,349 & $100.0 \%$ & 5,183 & $19.7 \%$ & 13,508 & $51.3 \%$ & 20,997 & $100.0 \%$ & 12,322 & $58.7 \%$ \\
\hline
\end{tabular}


TABLE 2

Descriptive Statistics and Correlations

Table 2 presents descriptive statistics for the variables used in the levels and changes analyses. As the SAME and COMP_HIGH variables are only used in the levels analyses, the number of observations is equal to 26,349 for the levels sample. As all other variables are used in both analyses, the number of observations equal to 44,756 , which is the sum of the two samples $(26,349+20,997)$ less 2,590 overlapping observations between the two samples. Panel A shows summary statistics and Panel B shows pair-wise Pearson (upper diagonal) and Spearman (lower diagonal) correlations for the variables. SAME is an indicator variable equal to one when the announcing and non-announcing firm-pair is using the same accounting standard and zero otherwise. COMP_HIGH is an indicator variable equal to one if the accounting standard correlation measure is above the median and zero otherwise. The accounting standard correlation measure is calculated based on the GAAP distance measure developed by Bae et al. (2008) and modified by Yu (2010). Price and volume data come from Datastream and analyst forecast data come from I/B/E/S. Data used to compute a firm's annual financial variables come from Worldscope and are measured at the end of a firm's fiscal year. CAR_2 (CAR_1) is the cumulative abnormal return for the non-announcing (announcing) firm, estimated using a two factor market model for the ( -1 , +1 ) event window around the announcing firm's earnings announcement day. The market model parameters are estimated over the period from 21 to 220 days before the announcement using returns from a value-weighted local market portfolio and a value-weighted world portfolio. AVOL_2 is the log of the average daily turnover during the event window, scaled by the median daily turnover during the estimation-period. UE_1 is the unexpected earnings for the announcing firm, calculated as actual earnings less the median analyst forecast scaled by the absolute value of the median analyst forecast. LOSS_1 is an indicator variable equal to one if the announcing firm's reported earnings is negative, and zero otherwise. SIZE_1 is the log of the market value of equity for the announcing firm. ANNLAG_1 is the announcing firm's reporting lag, calculated as the number of days from the firm's fiscal year-end to the earnings announcement date. SIZE_2 is the log of the market value of equity for the nonannouncing firm. NUMEST_2 is the number of unique analysts providing annual earnings forecast for the non-announcing firm. LEV_2 is the leverage ratio for the non-announcing firm, calculated as the ratio of total debt to total assets. BM_2 is the book-to-market ratio for the non-announcing firm, calculated as the book value of equity divided by the market value of equity. CORR is the correlation between the daily returns of announcing and of non-announcing firms in the prior year. FYOVLP is the number of overlapping days in the fiscal year between the announcing and non-announcing firm. Values for CAR_2, AVOL_2, UE_1, CAR_1, SIZE_1, SIZE_2, LEV_2, BM_2 and CORR have been winsorized at the $1^{\text {st }}$ and $99^{\text {th }}$ percentiles.

Panel A: Descriptive Statistics of Variables

\begin{tabular}{lcrrrrrrr}
\hline Variable & $\mathrm{n}$ & Mean & Std. Dev. & Min & Q1 & Median & Q3 & Max \\
\hline same & 26,349 & 0.197 & 0.398 & - & - & - & - & - \\
comp_high & 26,349 & 0.513 & 0.500 & - & - & - & - & - \\
car_2 & 44,756 & 0.001 & 0.041 & -0.128 & -0.019 & -0.001 & 0.019 & 0.151 \\
avol_2 & 44,756 & 0.162 & 1.021 & -3.073 & -0.408 & 0.146 & 0.732 & 3.005 \\
ue_1 & 44,756 & 0.008 & 0.343 & -1.833 & -0.027 & 0.009 & 0.071 & 1.573 \\
car_1 & 44,756 & 0.001 & 0.037 & -0.131 & -0.017 & -0.001 & 0.020 & 0.096 \\
loss_1 & 44,756 & 0.050 & 0.219 & - & - & - & - & - \\
size_1 & 44,756 & 9.714 & 1.398 & 6.954 & 8.599 & 9.791 & 10.858 & 12.295 \\
annlag_1 & 44,756 & 47.210 & 19.051 & 6.000 & 32.000 & 44.000 & 59.000 & 149.000 \\
size_2 & 44,756 & 5.873 & 1.784 & 0.545 & 4.684 & 5.822 & 7.026 & 10.541 \\
numest_2 & 44,756 & 5.561 & 5.830 & 1.000 & 1.000 & 3.000 & 8.000 & 55.000 \\
lev_2 & 44,756 & 0.210 & 0.160 & 0.000 & 0.066 & 0.200 & 0.326 & 0.629 \\
bm_2 & 44,756 & 0.725 & 0.616 & 0.062 & 0.345 & 0.551 & 0.890 & 4.023 \\
corr & 44,756 & 0.128 & 0.122 & -0.087 & 0.044 & 0.108 & 0.188 & 0.547 \\
fyovlp & 44,756 & 345.243 & 42.981 & 182.000 & 365.000 & 365.000 & 365.000 & 365.000 \\
\hline
\end{tabular}


TABLE 2 (Continued)

Descriptive Statistics and Correlations

Panel B: Pearson (upper diagonal) and Spearman (lower diagonal) Correlation of Variables

\begin{tabular}{|c|c|c|c|c|c|c|c|c|c|c|c|c|c|c|c|c|}
\hline Variable & $\mathrm{n}$ & same & $\begin{array}{r}\text { comp_ }_{-} \\
\text {high }\end{array}$ & car_2 & avol_2 & ue_1 & car_1 & loss_1 & size_1 & $\begin{array}{r}\text { ann- } \\
\text { lag_1 }\end{array}$ & size_2 & $\begin{array}{l}\text { num- } \\
\text { est_2 }\end{array}$ & lev_2 & $\mathrm{bm} \_2$ & corr & fyovlp \\
\hline same & 26,349 & & 0.480 & 0.010 & 0.010 & -0.060 & -0.010 & -0.080 & 0.160 & 0.020 & 0.120 & 0.130 & 0.050 & -0.020 & 0.270 & 0.120 \\
\hline comp_high & 26,349 & 0.480 & & 0.010 & 0.020 & -0.070 & -0.030 & -0.010 & 0.030 & -0.010 & 0.090 & 0.040 & 0.020 & -0.020 & 0.080 & -0.100 \\
\hline car_2 & 44,756 & 0.020 & 0.020 & & 0.130 & 0.010 & 0.010 & -0.010 & -0.010 & 0.000 & -0.010 & 0.000 & 0.000 & 0.020 & 0.010 & 0.030 \\
\hline avol_2 & 44,756 & 0.010 & 0.020 & 0.110 & & 0.050 & 0.010 & -0.010 & -0.030 & 0.010 & 0.010 & -0.020 & 0.010 & -0.070 & -0.060 & 0.020 \\
\hline ue_1 & 44,756 & -0.090 & -0.050 & 0.010 & 0.050 & & -0.040 & -0.480 & 0.010 & 0.050 & 0.020 & -0.020 & 0.010 & -0.050 & -0.050 & -0.010 \\
\hline car_1 & 44,756 & 0.000 & -0.040 & 0.010 & 0.000 & 0.000 & & -0.100 & 0.010 & 0.010 & -0.010 & 0.010 & -0.010 & 0.020 & 0.020 & -0.040 \\
\hline loss_1 & 44,756 & -0.080 & -0.010 & -0.010 & -0.010 & -0.270 & -0.100 & & -0.090 & 0.040 & -0.050 & -0.010 & -0.020 & 0.020 & 0.020 & 0.000 \\
\hline size_1 & 44,756 & 0.150 & 0.020 & -0.020 & -0.020 & -0.080 & 0.010 & -0.090 & & -0.410 & 0.020 & 0.040 & -0.070 & -0.040 & 0.130 & 0.020 \\
\hline annlag_1 & 44,756 & 0.040 & 0.030 & 0.000 & 0.000 & 0.060 & 0.030 & 0.040 & -0.410 & & 0.010 & -0.040 & 0.110 & 0.060 & -0.100 & -0.080 \\
\hline size_2 & 44,756 & 0.130 & 0.100 & 0.000 & 0.000 & 0.020 & -0.010 & -0.050 & 0.010 & 0.030 & & 0.620 & 0.120 & -0.340 & 0.340 & 0.040 \\
\hline numest_2 & 44,756 & 0.130 & 0.050 & 0.020 & -0.020 & -0.020 & 0.010 & -0.010 & 0.030 & -0.030 & 0.640 & & 0.050 & -0.180 & 0.420 & 0.020 \\
\hline lev_2 & 44,756 & 0.050 & 0.020 & 0.010 & 0.010 & 0.020 & 0.000 & -0.030 & -0.090 & 0.130 & 0.150 & 0.090 & & 0.100 & 0.020 & 0.030 \\
\hline bm_2 & 44,756 & -0.040 & -0.020 & 0.030 & -0.060 & -0.030 & 0.020 & 0.010 & -0.070 & 0.090 & -0.340 & -0.240 & 0.110 & & -0.030 & 0.010 \\
\hline corr & 44,756 & 0.240 & 0.060 & 0.010 & -0.070 & -0.050 & 0.020 & 0.030 & 0.110 & -0.090 & 0.300 & 0.350 & 0.020 & -0.060 & & 0.110 \\
\hline fyovlp & 44,756 & 0.110 & -0.100 & 0.030 & 0.030 & 0.060 & -0.040 & 0.020 & 0.000 & -0.080 & 0.040 & 0.010 & 0.040 & 0.010 & 0.100 & \\
\hline
\end{tabular}


TABLE 3

\section{Levels Analyses for Global Sample: Price Reaction}

Table 3 presents the results of OLS regression that models $\mathrm{CAR}_{2}$, non-announcing firms' abnormal returns. All variables are as defined in Table 2 . *, **, *** indicate significantly different from zero at the 0.10, 0.05, and 0.01 level, respectively, using a two-tailed test and standard errors clustered by announcement.

Model (1) and (2): $\mathrm{CAR}_{2 \mathrm{t}}=\alpha_{0}+\gamma_{1} \mathrm{UE}_{1 \mathrm{t}}+\alpha_{1} \mathrm{Same}_{12 \mathrm{t}}+\gamma_{2} \mathrm{Same}_{12 \mathrm{t}} * \mathrm{UE}_{1 \mathrm{t}}+\sum \beta_{\mathrm{k}} \mathrm{Ctrl}_{\mathrm{k}}+\varepsilon_{2 \mathrm{t}}$

Model (3) and (4): CAR $2 \mathrm{t}=\alpha_{0}+\gamma_{1} \mathrm{UE}_{1 \mathrm{t}}+\alpha_{1}$ Comp_High ${ }_{12 \mathrm{t}}+\gamma_{2} \mathrm{Comp}_{-} \operatorname{High}_{12 \mathrm{t}} * \mathrm{UE}_{1 \mathrm{t}}+\sum \beta_{\mathrm{k}} \mathrm{Ctrl} \mathrm{s}_{\mathrm{k}}+\varepsilon_{2 \mathrm{t}}$

\begin{tabular}{|c|c|c|c|c|c|c|c|c|c|c|c|c|c|}
\hline & \multirow[t]{2}{*}{ Pred. } & \multicolumn{2}{|c|}{$\begin{array}{c}\text { Domestic } \\
\text { Benchmark }\end{array}$} & \multicolumn{2}{|c|}{$\begin{array}{l}\text { Transnational } \\
\text { Benchmark }\end{array}$} & \multicolumn{2}{|c|}{ Model 1} & \multicolumn{2}{|c|}{ Model 2} & \multicolumn{2}{|c|}{ Model 3} & \multicolumn{2}{|c|}{ Model 4} \\
\hline & & coef. est. & t-stat & coef. est. & t-stat & coef. est. & t-stat & coef. est. & t-stat & coef. est. & t-stat & coef. est. & t-stat \\
\hline Intercept & & -0.0156 & -1.24 & 0.0159 & 1.29 & 0.0060 & 1.63 & 0.0159 & 1.30 & $0.0063 *$ & 1.79 & 0.0143 & 1.14 \\
\hline ue_1 & & $0.0059 * * *$ & 2.75 & 0.0019 & 0.81 & 0.0013 & 0.59 & 0.0013 & 0.57 & -0.0022 & -1.13 & -0.0021 & -1.04 \\
\hline same & & & & & & 0.0004 & 0.29 & 0.0004 & 0.26 & & & & \\
\hline same*ue_1 & + & & & & & $0.0069 *$ & 1.67 & $0.0072 *$ & 1.68 & & & & \\
\hline comp_high & & & & & & & & & & 0.0010 & 0.95 & 0.0009 & 0.87 \\
\hline comp_high*ue_1 & + & & & & & & & & & $0.0087 * *$ & 2.30 & $0.0087 * *$ & 2.27 \\
\hline car_1 & + & $0.0659 * *$ & 2.51 & 0.0134 & 0.72 & & & 0.0138 & 0.75 & & & 0.0138 & 0.75 \\
\hline loss_1 & - & 0.0025 & 0.74 & -0.0010 & -0.27 & & & -0.0011 & -0.30 & & & -0.0008 & -0.23 \\
\hline size_1 & & 0.0000 & -1.43 & -0.0014 & -1.18 & & & -0.0013 & -1.18 & & & -0.0012 & -1.01 \\
\hline annlag_1 & - & $0.0002 *$ & 1.72 & 0.0000 & 0.14 & & & 0.0000 & 0.14 & & & 0.0000 & 0.16 \\
\hline size_2 & - & 0.0000 & 0.80 & $-0.0005 *$ & -1.69 & & & $-0.0005 *$ & -1.68 & & & -0.0005 & -1.64 \\
\hline numest_2 & + & 0.0001 & 0.54 & 0.0001 & 1.11 & & & 0.0001 & 1.09 & & & 0.0001 & 1.04 \\
\hline lev_2 & & 0.0025 & 0.62 & -0.0007 & -0.36 & & & -0.0007 & -0.35 & & & -0.0008 & -0.42 \\
\hline bm_2 & & $0.0049 * * *$ & 3.99 & $0.0012 *$ & 1.72 & & & $0.0012 *$ & 1.72 & & & $0.0012 *$ & 1.71 \\
\hline corr & + & -0.0048 & -0.78 & 0.0010 & 0.20 & & & 0.0010 & 0.19 & & & 0.0009 & 0.18 \\
\hline fyovlp & + & 0.0000 & 0.74 & 0.0000 & 1.15 & & & 0.0000 & 1.14 & & & 0.0000 & 1.21 \\
\hline Cntry_2 fixed effects & & Yes & & Yes & & Yes & & Yes & & Yes & & Yes & \\
\hline Industry fixed effects & & Yes & & Yes & & Yes & & Yes & & Yes & & Yes & \\
\hline Year fixed effects & & Yes & & Yes & & Yes & & Yes & & Yes & & Yes & \\
\hline Month fixed effects & & Yes & & Yes & & Yes & & Yes & & Yes & & Yes & \\
\hline Adjusted R-squared & & 0.0344 & & 0.0077 & & 0.0069 & & 0.0078 & & 0.0076 & & 0.0084 & \\
\hline $\mathrm{N}$ (\# of firm-pair) & & 4,455 & & 26,349 & & 26,349 & & 26,349 & & 26,349 & & 26,349 & \\
\hline
\end{tabular}


TABLE 4

Levels Analyses for Global Sample: Volume Reaction

Table 4 presents the results of OLS regression that models $\mathrm{AVOL}_{2}$, non-announcing firms' abnormal volume. All variables are as defined in Table $2 . *$, **, *** indicate significantly different from zero at the $0.10,0.05$, and 0.01 level, respectively, using a two-tailed test and standard errors clustered by announcement.

Model (1) and (2): $\operatorname{AVOL}_{2 \mathrm{t}}=\alpha_{0}+\gamma_{1}\left|\mathrm{UE}_{1 \mathrm{t}}\right|+\alpha_{1} \mathrm{Same}_{12 \mathrm{t}}+\gamma_{2} \mathrm{Same}_{12 \mathrm{t}} *\left|\mathrm{UE}_{1 \mathrm{t}}\right|+\sum \beta_{\mathrm{k}} \mathrm{Ctrls}_{\mathrm{k}}+\varepsilon_{2 \mathrm{t}}$ Model (3) and (4): AVOL $2 \mathrm{t}=\alpha_{0}+\gamma_{1}\left|\mathrm{UE}_{1 \mathrm{t}}\right|+\alpha_{1}$ Comp_High $_{12 \mathrm{t}}+\gamma_{2}$ Comp_High $_{12 \mathrm{t}} *\left|\mathrm{UE}_{1 \mathrm{t}}\right|+\sum \beta_{\mathrm{k}} \mathrm{Ctrl}_{\mathrm{k}}+\varepsilon_{2 \mathrm{t}}$

\begin{tabular}{|c|c|c|c|c|c|c|c|c|c|c|c|c|c|}
\hline & \multirow{2}{*}{ Pred. } & \multicolumn{2}{|c|}{ Domestic } & \multicolumn{2}{|c|}{$\begin{array}{c}\text { Transnational } \\
\text { Benchmark }\end{array}$} & \multicolumn{2}{|c|}{ Model 1} & \multicolumn{2}{|c|}{ Model 2} & \multicolumn{2}{|c|}{ Model 3} & \multicolumn{2}{|c|}{ Model 4} \\
\hline & & coef. est. & t-stat & coef. est. & t-stat & coef. est. & t-stat & coef. est. & t-stat & coef. est. & t-stat & coef. est. & t-stat \\
\hline Intercept & & 0.0766 & 0.21 & -0.6140 & -1.35 & 0.0923 & 0.71 & -0.6241 & -1.37 & 0.1413 & 1.00 & -0.5646 & -1.24 \\
\hline abs_ue_1 & & $0.1173 * *$ & 1.97 & 0.0491 & 0.96 & 0.0331 & 0.71 & 0.0613 & 1.15 & -0.0574 & -1.03 & -0.0267 & -0.43 \\
\hline same & & & & & & 0.0279 & 0.89 & 0.0328 & 1.06 & & & & \\
\hline same*abs_ue_1 & + & & & & & 0.1404 & 1.63 & 0.1522 & 1.64 & & & & \\
\hline comp_high & & & & & & & & & & -0.0211 & -0.82 & -0.0106 & -0.43 \\
\hline comp_high*ue_1 & + & & & & & & & & & $0.1581 * *$ & 2.19 & $0.1457 *$ & 1.93 \\
\hline car_1 & + & 0.0337 & 0.05 & $0.6174 *$ & 1.89 & & & $0.6299 *$ & 1.92 & & & $0.6103 *$ & 1.88 \\
\hline loss_1 & - & -0.0957 & -1.06 & -0.0695 & -0.93 & & & -0.0735 & -0.98 & & & -0.0660 & -0.87 \\
\hline size_1 & & 0.0000 & -0.62 & 0.0516 & 1.32 & & & 0.0514 & 1.32 & & & 0.0492 & 1.27 \\
\hline annlag_1 & - & 0.0035 & 1.30 & $0.0032 *$ & 1.95 & & & $0.0032 *$ & 1.95 & & & $0.0033 * *$ & 1.97 \\
\hline size_2 & - & $0.0000 * *$ & -2.42 & 0.0110 & 1.37 & & & 0.0110 & 1.37 & & & 0.0108 & 1.34 \\
\hline numest_2 & + & 0.0022 & 0.68 & $-0.0046 * * *$ & -2.84 & & & $-0.0046 * * *$ & -2.86 & & & $-0.0046^{* * *}$ & -2.85 \\
\hline lev_2 & & $0.3593 * * *$ & 3.71 & 0.0728 & 1.61 & & & 0.0730 & 1.61 & & & 0.0700 & 1.55 \\
\hline fyovlp & + & -0.0010 & -1.40 & -0.0004 & -1.61 & & & -0.0004 & -1.64 & & & -0.0004 & -1.60 \\
\hline Cntry_2 fixed effects & & Yes & & Yes & & Yes & & Yes & & Yes & & Yes & \\
\hline Industry fixed effects & & Yes & & Yes & & Yes & & Yes & & Yes & & Yes & \\
\hline Year fixed effects & & Yes & & Yes & & Yes & & Yes & & Yes & & Yes & \\
\hline Month fixed effects & & Yes & & Yes & & Yes & & Yes & & Yes & & Yes & \\
\hline Adjusted R-squared & & 0.1086 & & 0.0644 & & 0.0626 & & 0.0645 & & 0.0628 & & 0.0648 & \\
\hline $\mathrm{N}$ (\# of firm-pair) & & 4,455 & & 26,349 & & 26,349 & & 26,349 & & 26,349 & & 26,349 & \\
\hline
\end{tabular}


TABLE 5

Cross-sectional Analyses for Global Sample: Price Reaction

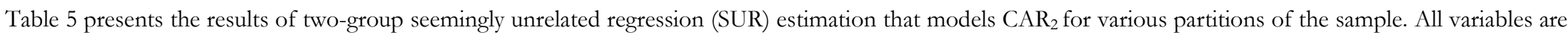
as defined in Table 2. I use the following variables to partition the sample: (1) The legal enforcement partition based on the rule of law variable for the year 2005 from Kaufmann et al. (2007); (2) The reporting incentives partition based on the aggregate earnings management score from Leuz et al. (2003), a measure I multiply by minus one so that higher values represent countries with less managed earnings thus stronger reporting incentives; (3) The economic integration partition based on whether the announcing firm and non-announcing firm are both member states of the EU including Norway and Switzerland; (4) The analyst overlap variable based on whether the firm-pair has any overlap in sell-side analyst coverage. I assess the statistical significance of the difference in coefficients between the partitions using chi-square tests and standard errors clustered by announcement. *, **, *** indicate significantly different from zero at the $0.10,0.05$, and 0.01 level, respectively, using a two-tailed test.

Model: $\mathrm{CAR}_{2 \mathrm{t}}=\alpha_{0}+\gamma_{1} \mathrm{UE}_{1 \mathrm{t}}+\alpha_{1}$ Comp_High ${ }_{12 \mathrm{t}}+\gamma_{2} \mathrm{Comp}_{-} \mathrm{High}_{12 \mathrm{t}} * \mathrm{UE}_{1 \mathrm{t}}+\sum \beta_{\mathrm{k}} \mathrm{Ctrls}_{\mathrm{k}}+\varepsilon_{2 \mathrm{t}}$

\begin{tabular}{|c|c|c|c|c|c|c|c|c|c|c|c|c|c|c|c|c|}
\hline & \multicolumn{4}{|c|}{ Legal Enforcement } & \multicolumn{4}{|c|}{ Reporting Incentives } & \multicolumn{4}{|c|}{ Economic Integration } & \multicolumn{4}{|c|}{ Analyst Overlap } \\
\hline & \multicolumn{2}{|c|}{ Strict } & \multicolumn{2}{|l|}{ Lax } & \multicolumn{2}{|c|}{ Strong } & \multicolumn{2}{|l|}{ Weak } & \multicolumn{2}{|c|}{ EU } & \multicolumn{2}{|c|}{ Non-EU } & \multicolumn{2}{|c|}{ Yes } & \multicolumn{2}{|l|}{ No } \\
\hline & coef. est. & t-stat & coef. est. & t-stat & coef. est. & t-stat & coef. est. & t-stat & coef. est. & t-stat & coef. est. & t-stat & coef. est. & t-stat & coef. est. & t-stat \\
\hline Intercept & 0.0049 & 0.41 & 0.0450 & 1.04 & $0.0799 *$ & 1.76 & 0.0057 & 0.37 & $-0.0258 *$ & -1.90 & $0.0846 *$ & 1.89 & -0.0086 & -0.30 & $0.0749 *$ & 1.72 \\
\hline ue_1 & 0.0019 & 1.11 & -0.0042 & -1.47 & -0.0002 & -0.09 & 0.0003 & 0.11 & 0.0015 & 0.90 & $0.0046 * * *$ & 2.78 & -0.0059 & -1.35 & 0.0002 & 0.15 \\
\hline comp & 0.0006 & 0.74 & 0.0012 & 1.11 & 0.0015 & 1.43 & 0.0004 & 0.44 & $-0.0027 * *$ & -2.08 & 0.0000 & -0.03 & -0.0016 & -0.82 & 0.0009 & 1.40 \\
\hline comp_high*ue_1 & $0.0110 * * *$ & 4.54 & -0.0038 & -0.91 & $0.0134 * * *$ & 4.97 & 0.0019 & 0.55 & $0.0132 * * *$ & 2.79 & 0.0010 & 0.15 & 0.0049 & 0.82 & $0.0086 * * *$ & 3.94 \\
\hline car_1 & 0.0130 & 1.24 & 0.0091 & 0.54 & $-0.0269 * *$ & -2.11 & $0.0563 * * *$ & 4.49 & $0.0364 * * *$ & 3.19 & -0.0042 & -0.34 & $0.0798 * * *$ & 3.43 & 0.0053 & 0.59 \\
\hline loss_1 & 0.0034 & 1.28 & -0.0023 & -1.03 & -0.0007 & -0.33 & 0.0045 & 1.01 & 0.0034 & 1.17 & 0.0001 & 0.02 & $0.0132 * *$ & 2.02 & -0.0003 & -0.19 \\
\hline size_1 & -0.0003 & -0.30 & $0.0026 *$ & 1.73 & -0.0007 & -0.59 & -0.0003 & -0.17 & 0.0016 & 1.31 & $-0.0024 * *$ & -2.27 & -0.0009 & -0.36 & -0.0008 & -0.99 \\
\hline annlag_1 & $-0.0001 * *$ & -2.53 & 0.0000 & -0.03 & 0.0000 & -0.48 & -0.0001 & -1.55 & 0.0000 & -0.94 & 0.0000 & 0.18 & 0.0000 & 0.55 & 0.0000 & -1.48 \\
\hline size_2 & -0.0003 & -0.98 & -0.0005 & -1.44 & -0.0002 & -0.52 & -0.0006 & -1.63 & -0.0005 & -1.38 & -0.0004 & -1.05 & -0.0003 & -0.34 & $-0.0005 *$ & -1.74 \\
\hline numest_2 & 0.0001 & 1.19 & 0.0000 & -0.04 & 0.0000 & -0.49 & $0.0002 *$ & 1.66 & $0.0002 * *$ & 2.50 & -0.0001 & -0.68 & 0.0001 & 0.39 & 0.0001 & 1.26 \\
\hline lev_2 & -0.0031 & -1.29 & 0.0024 & 0.91 & -0.0019 & -0.76 & 0.0006 & 0.25 & -0.0017 & -0.64 & -0.0005 & -0.22 & $-0.0100 *$ & -1.69 & -0.0006 & -0.33 \\
\hline bm_2 & 0.0010 & 1.53 & $0.0016 * *$ & 2.32 & 0.0002 & 0.33 & $0.0024 * * *$ & 3.59 & $0.0013 *$ & 1.73 & 0.0009 & 1.47 & 0.0022 & 1.02 & $0.0011 * *$ & 2.31 \\
\hline corr & -0.0009 & -0.24 & 0.0061 & 1.35 & 0.0001 & 0.02 & 0.0020 & 0.51 & -0.0050 & -1.31 & $0.0086 *$ & 1.93 & 0.0011 & 0.15 & 0.0002 & 0.07 \\
\hline fyovlp & 0.0000 & -0.05 & $0.0000 * *$ & 2.26 & $0.0000 * * *$ & 3.62 & 0.0000 & -1.03 & $0.0000 * *$ & 2.01 & $0.0000 * *$ & 2.47 & 0.0000 & 0.90 & $0.0000 * *$ & 2.22 \\
\hline Cntry_2 fixed effects & Yes & & Yes & & Yes & & Yes & & Yes & & Yes & & Yes & & Yes & \\
\hline Industry fixed effects & Yes & & Yes & & Yes & & Yes & & Yes & & Yes & & Yes & & Yes & \\
\hline Year fixed effects & Yes & & Yes & & Yes & & Yes & & Yes & & Yes & & Yes & & Yes & \\
\hline Month fixed effects & Yes & & Yes & & Yes & & Yes & & Yes & & Yes & & Yes & & Yes & \\
\hline N (\# of firm-pair) & 15,580 & & 10,769 & & 12,554 & & 13,290 & & 11,415 & & 14,934 & & 2,199 & & 24,150 & \\
\hline $\begin{array}{l}\text { Test for coef. diff. } \\
\text { comp_high*ue_1 } \\
\text { chi-square }\end{array}$ & & $\begin{array}{r}0.0 \\
9\end{array}$ & $\begin{array}{l}48 \\
.45^{* * *}\end{array}$ & & & & $\begin{array}{l}114 \\
6.73 * * *\end{array}$ & & & $\begin{array}{r}0.01 \\
2 .\end{array}$ & $\begin{array}{l}22 \\
.23\end{array}$ & & & $\begin{array}{r}-0.00 \\
0 .\end{array}$ & 37 & \\
\hline
\end{tabular}


TABLE 6

Cross-sectional Analyses for Global Sample: Volume Reaction

Table 6 presents the results of two-group seemingly unrelated regression (SUR) estimation that models AVOL 2 for various partitions of the sample. All variables are as defined in Table 2. I use the following variables to partition the sample: (1) The legal enforcement partition based on the rule of law variable for the year 2005 from Kaufmann, Kraay and Mastruzzi (2007); (2) The reporting incentives partition based on the aggregate earnings management score from Leuz, Nanda and Wysocki (2003), a measure I multiply by minus one so that higher values represent countries with less managed earnings thus stronger reporting incentives; (3) The economic integration partition based on whether the announcing firm and non-announcing firm are both member states of the EU including Norway and Switzerland; (4) The analyst overlap variable based on whether the firm-pair has any overlap in sell-side analyst coverage. I assess the statistical significance of the difference in coefficients between the partitions using chi-square tests and standard errors clustered by announcement. *, **, *** indicate significantly different from zero at the 0.10 , 0.05 , and 0.01 level, respectively, using a two-tailed test.

Model: AVOL $2 \mathrm{t}=\alpha_{0}+\gamma_{1}\left|\mathrm{UE}_{1 \mathrm{t}}\right|+\alpha_{1}$ Comp_High $_{12 \mathrm{t}}+\gamma_{2}$ Comp_High $_{12 \mathrm{t}} *\left|\mathrm{UE}_{1 \mathrm{t}}\right|+\sum \beta_{\mathrm{k}} \mathrm{Ctrl}_{\mathrm{k}}+\varepsilon_{2 \mathrm{t}}$

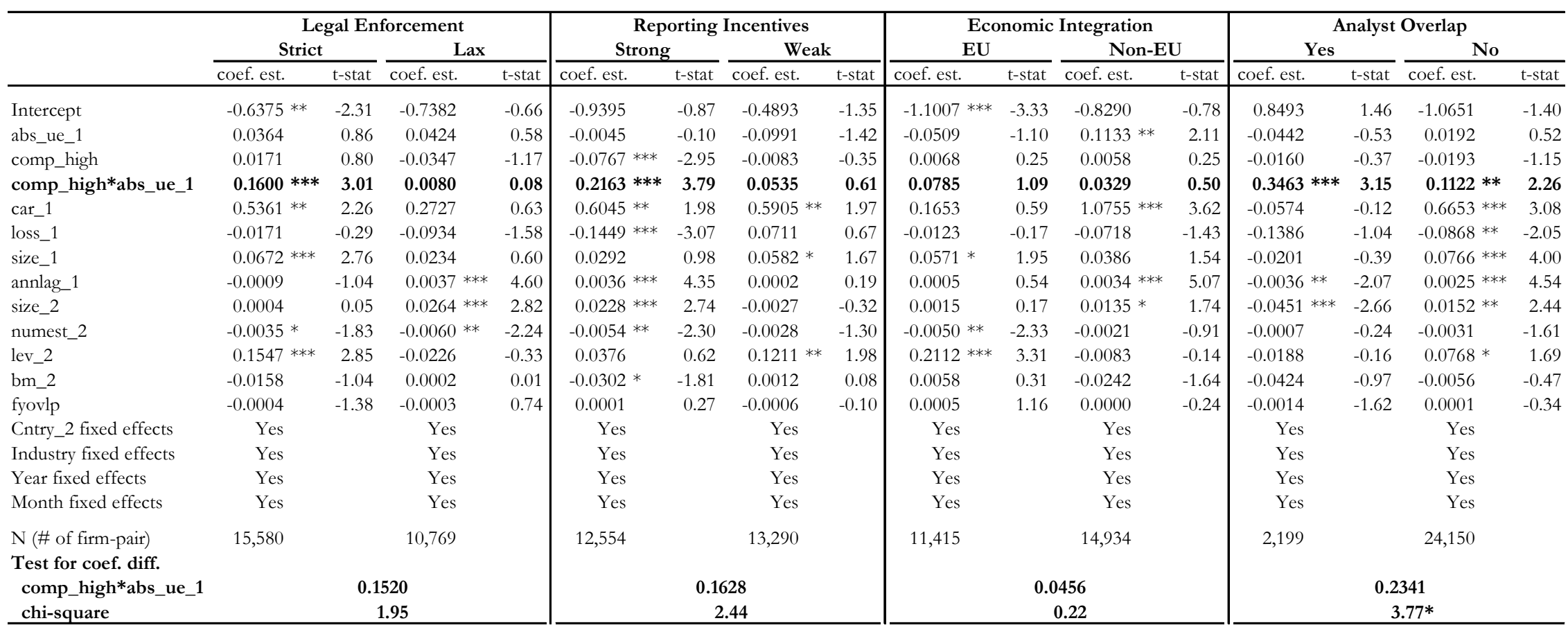




\section{TABLE 7}

\section{Changes Analyses around the IFRS Mandate: Price Reaction}

Table 7 presents the difference-in-differences analyses based on firm-pair observations from the treatment group (announcing firms are voluntary IFRS adopters and non-announcing firms are mandatory IFRS adopters) and the benchmark group (announcing firms are voluntary IFRS adopters and non-announcing firms are non-IFRS adopters) with data available both pre- and post-mandatory IFRS adoption. Panel A reports mean values of the dependent variable $\left(\mathrm{CAR}_{2}\right)$ and the number of observations. I assess the statistical significance of the difference-in-differences values by comparing means of changes across the two groups using t-tests. Panel B reports $\gamma$, the information transfer ERC, for each group estimated jointly using seemingly unrelated regression (SUR) with all control variables described in the levels analyses. I assess the statistical significance of the difference in coefficients using chi-square tests and standard errors clustered by announcement. ${ }^{*},{ }^{* *},{ }^{* *}$ indicate significantly different from zero at the $0.10,0.05$, and 0.01 level (twotailed), respectively.

\section{Panel A: Univariate $\mathrm{CAR}_{2}$ Comparison}

\begin{tabular}{|c|c|c|c|c|c|}
\hline & & $\begin{array}{c}2001 \text { - } 2004 \\
\text { Pre-Mandatory } \\
\text { Adoption } \\
\text { (a) } \\
\end{array}$ & $\begin{array}{c}2005 \text { - } 2008 \\
\text { Post-Mandatory } \\
\text { Adoption } \\
\text { (b) } \\
\end{array}$ & $\begin{array}{l}\text { Difference } \\
\text { (b) - (a) }\end{array}$ & t-stat \\
\hline $\begin{array}{l}\text { Firm1: Voluntary Adopters } \\
\text { Firm2: Mandatory Adopters }\end{array}$ & (i) & $\begin{array}{c}0.0002 \\
n=5,556\end{array}$ & $\begin{array}{c}0.0036 \\
n=6,766\end{array}$ & $0.0034 * * *$ & 5.05 \\
\hline $\begin{array}{l}\text { Firm1: Voluntary Adopters } \\
\text { Firm2: Non-Adopters }\end{array}$ & (ii) & $\begin{array}{c}0.0006 \\
n=3,426\end{array}$ & $\begin{array}{c}0.0008 \\
n=5,249\end{array}$ & 0.0002 & 0.23 \\
\hline $\begin{array}{l}\text { Difference } \\
\text { t-stat }\end{array}$ & (i) - (ii) & $\begin{array}{c}-0.0003 \\
-0.41\end{array}$ & $\begin{array}{l}0.0028^{* * *} \\
3.93\end{array}$ & $0.0032 * * *$ & 3.82 \\
\hline
\end{tabular}

Panel B: SUR Estimation - $\gamma$ Comparison

Model: $\mathrm{CAR}_{2 \mathrm{t}}=\alpha+\gamma \mathrm{UE}_{1 \mathrm{t}}+\sum \beta_{\mathrm{k}} \mathrm{Ctrls}_{\mathrm{k}}+\varepsilon_{2 \mathrm{t}}$

\begin{tabular}{|c|c|c|c|c|c|}
\hline & & $\begin{array}{c}2001-2004 \\
\text { Pre-Mandatory } \\
\text { Adoption } \\
\text { (a) }\end{array}$ & $\begin{array}{c}2005-2008 \\
\text { Post-Mandatory } \\
\text { Adoption } \\
\text { (b) } \\
\end{array}$ & $\begin{array}{l}\text { Difference } \\
\text { (b) - (a) }\end{array}$ & chi-square \\
\hline $\begin{array}{l}\text { Firm1: Voluntary Adopters } \\
\text { Firm2: Mandatory Adopters }\end{array}$ & (i) & $\begin{array}{l}-0.0019 \\
n=5,556\end{array}$ & $\begin{array}{c}0.0027 \\
n=6,766\end{array}$ & $0.0046 *$ & 3.11 \\
\hline $\begin{array}{l}\text { Firm1: Voluntary Adopters } \\
\text { Firm2: Non-Adopters }\end{array}$ & (ii) & $\begin{array}{c}0.0015 \\
n=3,426\end{array}$ & $\begin{array}{l}-0.0036 \\
n=5,249\end{array}$ & -0.0051 & 2.59 \\
\hline $\begin{array}{l}\text { Difference } \\
\text { chi-square }\end{array}$ & (i) - (ii) & $\begin{array}{c}-0.0034 \\
0.91 \\
\end{array}$ & $\begin{array}{l}0.0063^{* * *} \\
9.72 \\
\end{array}$ & $0.0097 * *$ & 5.59 \\
\hline
\end{tabular}




\section{TABLE 8}

\section{Changes Analyses around the IFRS Mandate: Volume Reaction}

Table 8 presents the difference-in-differences analyses based on firm-pair observations from the treatment group (announcing firms are voluntary IFRS adopters and non-announcing firms are mandatory IFRS adopters) and the benchmark group (announcing firms are voluntary IFRS adopters and non-announcing firms are non-IFRS adopters) with data available both pre- and post-mandatory IFRS adoption. Panel A reports mean values of the dependent variable $\left(\mathrm{AVOL}_{2}\right)$ and the number of observations. I assess the statistical significance of the difference-in-differences values by comparing means of changes across the two groups using t-tests. Panel B reports $\gamma$, the information transfer ERC, for each group estimated jointly using seemingly unrelated regression (SUR) with all control variables described in the levels analyses. I assess the statistical significance of the difference in coefficients using chi-square tests and standard errors clustered by announcement. *,**, *** indicate significantly different from zero at the 0.10, 0.05, and 0.01 level (twotailed), respectively.

Panel A: Univariate $\mathrm{AVOL}_{2}$ Comparison

\begin{tabular}{|c|c|c|c|c|c|}
\hline & & $\begin{array}{c}2001-2004 \\
\text { Pre-Mandatory } \\
\text { Adoption } \\
\text { (a) } \\
\end{array}$ & $\begin{array}{c}2005-2008 \\
\text { Post-Mandatory } \\
\text { Adoption } \\
\text { (b) }\end{array}$ & $\begin{array}{l}\text { Difference } \\
\text { (b) - (a) }\end{array}$ & t-stat \\
\hline $\begin{array}{l}\text { Firm1: Voluntary Adopters } \\
\text { Firm2: Mandatory Adopters }\end{array}$ & (i) & $\begin{array}{c}0.1499 \\
n=5,556\end{array}$ & $\begin{array}{c}0.4109 \\
n=6,766\end{array}$ & $0.2610 * * *$ & 14.49 \\
\hline $\begin{array}{l}\text { Firm1: Voluntary Adopters } \\
\text { Firm2: Non-Adopters }\end{array}$ & (ii) & $\begin{array}{c}0.0332 \\
n=3,426\end{array}$ & $\begin{array}{c}0.2063 \\
n=5,249\end{array}$ & $0.1731 * * *$ & 8.17 \\
\hline $\begin{array}{l}\text { Difference } \\
\text { t-stat }\end{array}$ & (i) - (ii) & $\begin{array}{c}0.1167^{* * *} \\
6.69\end{array}$ & $\begin{array}{l}0.2046^{* * *} \\
9.45\end{array}$ & $0.0879 * * *$ & 3.60 \\
\hline
\end{tabular}

Panel B: SUR Estimation - $\gamma$ Comparison

Model: $\mathrm{AVOL}_{2 \mathrm{t}}=\alpha+\gamma\left|\mathrm{UE}_{1 \mathrm{t}}\right|+\sum \beta_{\mathrm{k}} \mathrm{Ctrls}_{\mathrm{k}}+\varepsilon_{2 \mathrm{t}}$

\begin{tabular}{|c|c|c|c|c|c|}
\hline & & $\begin{array}{c}2001-2004 \\
\text { Pre-Mandatory } \\
\text { Adoption } \\
\text { (a) } \\
\end{array}$ & $\begin{array}{c}2005-2008 \\
\text { Post-Mandatory } \\
\text { Adoption } \\
\text { (b) } \\
\end{array}$ & $\begin{array}{l}\text { Difference } \\
\text { (b) - (a) }\end{array}$ & chi-square \\
\hline $\begin{array}{l}\text { Firm1: Voluntary Adopters } \\
\text { Firm2: Mandatory Adopters }\end{array}$ & (i) & $\begin{array}{c}-0.0093 \\
n=5,556\end{array}$ & $\begin{array}{c}0.2434 \\
n=6,766\end{array}$ & 0.2527 *** & 10.31 \\
\hline $\begin{array}{l}\text { Firm1: Voluntary Adopters } \\
\text { Firm2: Non-Adopters }\end{array}$ & (ii) & $\begin{array}{c}-0.0154 \\
n=3,426\end{array}$ & $\begin{array}{c}0.0456 \\
n=5,249\end{array}$ & 0.0610 & 0.71 \\
\hline $\begin{array}{l}\text { Difference } \\
\text { chi-square }\end{array}$ & (i) - (ii) & $\begin{array}{c}0.0061 \\
0.02\end{array}$ & $\begin{array}{c}0.1978^{* *} \\
4.08\end{array}$ & $0.1917 *$ & 3.19 \\
\hline
\end{tabular}


TABLE 9

\section{Additional Analyses: Correlation in Unexpected Earnings}

Table 9 presents the results of OLS regression to test the correlation of unexpected earnings between the firm-pairs for the levels analyses sample. UE_ 2 is the unexpected earnings for the non-announcing firm, calculated as actual earnings less the median analyst forecast scaled by the absolute value of the median analyst forecast measured at the announcing firm's earnings announcement date. All other variables are as defined in Table $2 . *$, **, *** indicate significantly different from zero at the 0.10, 0.05, and 0.01 level, respectively, using a two-tailed test and standard errors clustered by announcement.

Model (1) and (2): $\mathrm{UE}_{2 \mathrm{t}}=\alpha_{0}+\gamma_{1} \mathrm{UE}_{1 \mathrm{t}}+\alpha_{1} \mathrm{Same}_{12 \mathrm{t}}+\gamma_{2} \mathrm{Same}_{12 \mathrm{t}} * \mathrm{UE}_{1 \mathrm{t}}+\sum \beta_{\mathrm{k}} \mathrm{Ctrls}_{\mathrm{k}}+\varepsilon_{2 \mathrm{t}}$

$\operatorname{Model}(3)$ and (4): $\mathrm{UE}_{2 \mathrm{t}}=\alpha_{0}+\gamma_{1} \mathrm{UE}_{1 \mathrm{t}}+\alpha_{1}$ Comp_High $12 \mathrm{t}+\gamma_{2} \mathrm{Comp}_{\text {High }} \mathrm{Hit}_{\mathrm{t}} * \mathrm{UE}_{1 \mathrm{t}}+\sum \beta_{\mathrm{k}} \mathrm{Ctrl}_{\mathrm{k}}+\varepsilon_{2 \mathrm{t}}$

\begin{tabular}{|c|c|c|c|c|c|c|c|c|c|c|c|c|c|}
\hline & \multirow[t]{2}{*}{ Pred. } & \multicolumn{2}{|c|}{ Domestic } & \multicolumn{2}{|c|}{$\begin{array}{c}\text { Transnational } \\
\text { Benchmark }\end{array}$} & \multicolumn{2}{|c|}{ Model 1} & \multicolumn{2}{|c|}{ Model 2} & \multicolumn{2}{|c|}{ Model 3} & \multicolumn{2}{|c|}{ Model 4} \\
\hline & & coef. est. & t-stat & coef. est. & t-stat & coef. est. & t-stat & coef. est. & t-stat & coef. est. & t-stat & coef. est. & t-stat \\
\hline Intercept & & $-0.9735 * *$ & -1.97 & -0.5826 & -3.98 & -0.3526 & -3.31 & -0.5401 & -3.74 & -0.3714 & -3.37 & -0.5524 & -3.72 \\
\hline ue_1 & & $0.0197 * *$ & 2.40 & 0.1767 & 3.02 & 0.1507 & 2.66 & 0.1467 & 2.54 & -0.0130 & -0.56 & $-0.0217 *$ & -0.93 \\
\hline same & & & & & & $-0.0583 * * *$ & -1.87 & $-0.0922 * * *$ & -2.87 & & & & \\
\hline same*ue_1 & + & & & & & $0.3067 * *$ & 2.43 & $0.3144 * *$ & 2.53 & & & & \\
\hline comp_high & & & & & & & & & & 0.1574 & 1.73 & 0.1531 & 1.64 \\
\hline comp_high*ue_1 & + & & & & & & & & & 0.0423 & 0.36 & 0.0454 & 0.38 \\
\hline corr & + & $0.3938 * *$ & 2.09 & $0.6155 * * *$ & 5.90 & & & $0.6566 * * *$ & 6.16 & & & $0.6202 * * *$ & 5.91 \\
\hline fyovlp & + & 0.0020 & 1.19 & 0.0001 & 0.37 & & & 0.0001 & 0.41 & & & $0.0001 *$ & 0.33 \\
\hline anaovlp & + & $0.0151 * * *$ & 3.40 & 0.0028 & 1.06 & & & 0.0027 & 0.99 & & & 0.0029 & 1.07 \\
\hline Cntry_2 fixed effects & & Yes & & Yes & & Yes & & Yes & & Yes & & Yes & \\
\hline Industry fixed effects & & Yes & & Yes & & Yes & & Yes & & Yes & & Yes & \\
\hline Year fixed effects & & Yes & & Yes & & Yes & & Yes & & Yes & & Yes & \\
\hline Month fixed effects & & Yes & & Yes & & Yes & & Yes & & Yes & & Yes & \\
\hline $\mathrm{N}$ (\# of firm-pair) & & 4,455 & & 26,349 & & 26,349 & & 26,349 & & 26,349 & & 26,349 & \\
\hline
\end{tabular}

